\title{
A Dual Noradrenergic Mechanism for the Relief of Neuropathic Allodynia by the Antidepressant Drugs Duloxetine and Amitriptyline
}

\author{
Mélanie Kremer, ${ }^{1}$ Ipek Yalcin, ${ }^{1}$ Yannick Goumon, ${ }^{1}$ Xavier Wurtz, ${ }^{1}$ Laurent Nexon, ${ }^{1}$ Dorothée Daniel, ${ }^{1}$ Salim Megat, ${ }^{1}$ \\ Rhian A. Ceredig, ${ }^{1}$ Carl Ernst, ${ }^{3}$ C Gustavo Turecki, ${ }^{3}$ Virginie Chavant, ${ }^{1}$ Jean-François Théroux, ${ }^{3}$ Adrien Lacaud, ${ }^{1}$ \\ Lauriane-Elisabeth Joganah, ${ }^{4}$ Vincent Lelievre, ${ }^{1}$ Dominique Massotte, ${ }^{1}$ DPierre-Eric Lutz, ${ }^{1,3}$ Ralf Gilsbach, ${ }^{2}$ \\ Eric Salvat, ${ }^{1,4}$ and Michel Barrot ${ }^{1}$ \\ ${ }^{1}$ Centre National de la Recherche Scientifique, Université de Strasbourg, Institut des Neurosciences Cellulaires et Intégratives, 67000 Strasbourg, France, \\ ${ }^{2}$ Institute of Experimental and Clinical Pharmacology and Toxicology, Faculty of Medicine, University of Freiburg, 79104 Freiburg, Germany, ${ }^{3}$ Douglas \\ Mental Health University Institute, McGill University, Montréal, QC, H4H 1R3, Canada, and ${ }^{4}$ Centre d'Etude et de Traitement de la Douleur, Hôpitaux \\ Universitaires de Strasbourg, 67000 Strasbourg, France
}

In addition to treating depression, antidepressant drugs are also a first-line treatment for neuropathic pain, which is pain secondary to lesion or pathology of the nervous system. Despite the widespread use of these drugs, the mechanism underlying their therapeutic action in this pain context remains partly elusive. The present study combined data collected in male and female mice from a model of neuropathic pain and data from the clinical setting to understand how antidepressant drugs act. We show two distinct mechanisms by which the selective inhibitor of serotonin and noradrenaline reuptake duloxetine and the tricyclic antidepressant amitriptyline relieve neuropathic allodynia. One of these mechanisms is acute, central, and requires descending noradrenergic inhibitory controls and $\alpha_{2 \mathrm{~A}}$ adrenoceptors, as well as the mu and delta opioid receptors. The second mechanism is delayed, peripheral, and requires noradrenaline from peripheral sympathetic endings and $\beta_{2}$ adrenoceptors, as well as the delta opioid receptors. We then conducted a transcriptomic analysis in dorsal root ganglia, which suggested that the peripheral component of duloxetine action involves the inhibition of neuroimmune mechanisms accompanying nerve injury, including the downregulation of the TNF- $\alpha-\mathrm{NF}-\kappa \mathrm{B}$ signaling pathway. Accordingly, immunotherapies against either TNF- $\alpha$ or Toll-like receptor 2 (TLR2) provided allodynia relief. We also compared duloxetine plasma levels in the animal model and in patients and we observed that patients' drug concentrations were compatible with those measured in animals under chronic treatment involving the peripheral mechanism. Our study highlights a peripheral neuroimmune component of antidepressant drugs that is relevant to their delayed therapeutic action against neuropathic pain.

Key words: amitriptyline; antidepressants; duloxetine; neuropathic pain; TLR2; TNF- $\alpha$

Significance Statement

In addition to treating depression, antidepressant drugs are also a first-line treatment for neuropathic pain, which is pain secondary to lesion or pathology of the nervous system. However, the mechanism by which antidepressant drugs can relieve neuropathic pain remained in part elusive. Indeed, preclinical studies led to contradictions concerning the anatomical and molecular substrates of this action. In the present work, we overcame these apparent contradictions by highlighting the existence of two independent mechanisms. One is rapid and centrally mediated by descending controls from the brain to the spinal cord and the other is delayed, peripheral, and relies on the anti-neuroimmune action of chronic antidepressant treatment.

\section{Introduction}

Understanding the mechanisms underlying currently used pharmacological treatments of a disease can be critical to provide

Received April 11, 2018; revised June 27, 2018; accepted July 22, 2018.

Author contributions: M.K. wrote the first draft of the paper; I.Y., D.M., and M.B. designed research; M.K., I.Y., Y.G., X.W., L.N., D.D., S.M., R.A.C., C.E., G.T., V.C., J.-F.T., A.L., L.-E.J., P.-E.L., R.G., and E.S. performed research; M.K., Y.G., V.L., P.-E.L., R.G., and M.B. analyzed data; M.K. and M.B. wrote the paper. insights into the pathology itself and hints toward new treatments. In the early 1960s, it was fortuitously observed that a

This work was supported by the Centre National de la Recherche Scientifique (CNRS, contract UPR3212) and the Université de Strasbourg (UPR3212), the Agence Nationale de la Recherche (Euridol ANR-17-EURE-0022), a CNRS disability doctoral fellowship (M.K.), the Fondation d'Entreprise Banque Populaire (M.K.), Fédéeh-Hewlett-Packard (M.K.), the Fondation pour la Recherche Médicale (P.-E.L.), the Fondation Pierre Deniker (P.-E.L.), the Institut UPSA de la Douleur (M.B.). We thank Stéphane Doridot (Chronobiotron, UMS3415 (NRS) for animal care and genotyping We thank Prof. Brigitte Kieffer (McGill University, Canada) and Prof. Claire Gavériaux-Ruff (IGBMC, France) for 
tricylic antidepressant used in the psychiatry field might also relieve neuropathic pain (Paoli et al., 1960), which is pain consecutive to a lesion or pathology of the somatosensory system (Treede et al., 2008). In the 1970s and 1980s, this observation was confirmed by controlled studies (Watson et al., 1982; Max et al., 1987) and tricylic antidepressants were recognized as first-line treatments against neuropathic pain (Finnerup et al., 2015), this action being clinically disconnected from their impact on depression (Micó et al., 2006; Perahia et al., 2006). Early in this century, antidepressants that are more selective inhibitors of serotonin and noradrenaline reuptake (SSNRIs), such as duloxetine, were approved by various agencies as treatment for painful diabetic peripheral neuropathy (Kremer et al., 2016a). Today, these drugs are frequently used to treat a wide variety of neuropathic pain. However, detailed mechanism by which antidepressant drugs relieve painful symptoms remains elusive, with apparent contradictions in the scientific literature (Kremer et al., 2016a). It is often acknowledged that antidepressants would act through descending aminergic pathways from the locus coeruleus to the spinal cord and inhibit nociceptive processing (Ardid and Guilbaud, 1992; Suzuki et al., 2008; Arsenault and Sawynok, 2009). However, a peripheral mechanism has also been proposed to explain the action of the tricyclic antidepressant nortriptyline (Bohren et al., 2013). Whereas a main contribution of $\alpha_{2}$ adrenoceptors is usually considered as critical (Ozdoğan et al., 2004; Cegielska-Perun et al., 2013; Hajhashemi et al., 2014), a loss of anti-allodynic action has been observed for certain antidepressant drugs in mice deficient for $\beta_{2}$ adrenoceptors (Yalcin et al., 2009a,b; Bohren et al., 2013; Choucair-Jaafar et al., 2014). In addition, despite general consensus about involvement of opioid receptors, discrepancies remain as to receptor type and anatomical localization (Schreiber et al., 1999; Marchand et al., 2003; Benbouzid et al., 2008b; Bohren et al., 2010; Choucair-Jaafar et al., 2014; Megat et al., 2015).

Here, we investigated the anti-allodynic action of the SSNRI duloxetine in two different paradigms in a mouse model of neuropathic pain. We also compared plasma concentrations in these procedures to those observed in the clinical setting. We show that duloxetine and the tricylic antidepressant amitriptyline exert acute anti-allodynic action through central $\alpha_{2 \mathrm{~A}}$ adrenoceptor-dependent mechanism and chronic pain relief through a peripheral and $\beta_{2}$ adrenoceptors dependent mechanism that relies on an anti-neuroimmune action of the drug. We further substantiate our findings by bringing evidence that the peripheral mechanism is compatible with plasma levels of duloxetine in patients.

\section{Materials and Methods \\ Study}

The purpose of this study was to understand how duloxetine relieves neuropathic pain. Using a mouse model, a mechanistic dissection was performed and compared with the action of a tricyclic antidepressant, amitriptyline. Results highlighted that two independent mechanisms can mediate the action of duloxetine. A co-clinical study was then conducted to compare the plasma levels of duloxetine in neuropathic pain patients and in an animal model. Because the results highlighted the possible relevance of the chronic mechanism of duloxetine, we further explored

providing MOR, DOR, and KOR related mouse breeders and the Ecole Universitaire de Recherche Euridol (Programme d'Investissements d'Avenir).

The authors declare no competing financial interests.

Correspondence should be addressed to Michel Barrot, Centre National de la Recherche Scientifique, Université de Strasbourg, Institut des Neurosciences Cellulaires et Intégratives, 5 rue Blaise Pascal, 67000 Strasbourg, France. E-mail:mbarrot@inci-cnrs.unistra.fr.

https://doi.org/10.1523/JNEUROSCl.1004-18.2018

Copyright $\odot 2018$ the authors $\quad 0270-6474 / 18 / 389935-21 \$ 15.00 / 0$ this mechanism by a transcriptomic analysis. A schematic of the time course of experimental procedures is presented in Figure 1.

\section{Animals}

All animal studies were performed in agreement with European guidelines (EU 2010/63) and under protocols approved by the Comité d'Ethique en Matière d'Expérimentation Animale de Strasbourg (CREMEAS, CEEA35). Experiments were performed using C57BL/6J mice (Charles River Laboratories), $8-10$ weeks old at surgery time, or with male and female mice lacking $\beta_{2}$ adrenoceptors, $\mu$-opioid receptors (MOR), $\delta$-opioid receptors (DOR), or $\kappa$-opioid receptors (KOR) and their littermate controls. The generation of mice lacking MOR, DOR, or KOR, created in the laboratory of Brigitte Kieffer (IGBMC, Strasbourg, France), has been described previously (Matthes et al., 1996; Simonin et al., 1998; Filliol et al., 2000). Mice lacking $\beta_{2}$ adrenoceptors were created in the laboratory of Brian Kobilka (Stanford University, Stanford, CA) and have been described previously (Chruscinski et al., 1999). Heterozygote mice were bred in our animal facilities, genotyping of the litters was done, and the experiments were conducted on adult male and female WT and KO littermate mice weighing 20-30 g. The same number of males and females was used in each experimental group. Because the WT animals have the same background and the same behavioral phenotype, they were pooled to form the control groups. Mice were group-housed two to five per cage and kept under a $12 \mathrm{~h}$ light/dark cycle with food and water ad libitum. In pharmacological studies, mice were randomly assigned to experimental groups. The experimenter was always blinded to both genotype and treatment.

\section{Neuropathic pain model}

Neuropathic pain was induced by cuffing the main branch of the right sciatic nerve (Benbouzid et al., 2008a; Yalcin et al., 2014). Surgeries were performed under ketamine $(68 \mathrm{mg} / \mathrm{kg}) / x y l a z i n e ~(10 \mathrm{mg} / \mathrm{kg})$ intraperitoneal anesthesia (Centravet). The common branch of the right sciatic nerve was exposed and a cuff of PE-20 polyethylene tubing (Harvard Apparatus) of standardized length $(2 \mathrm{~mm})$ was unilaterally inserted around it (Cuff group). The shaved skin was closed using suture. Shamoperated mice underwent the same surgical procedure without implantation of the cuff (Sham group).

\section{Measure of mechanical allodynia}

Mechanical allodynia (a symptom of neuropathic pain) was tested using von Frey hairs and results were expressed in grams (Barrot, 2012). Tests were performed during the morning starting at least $2 \mathrm{~h}$ after lights on. Mice were placed in clear Plexiglas boxes $(7 \mathrm{~cm} \times 9 \mathrm{~cm} \times 7 \mathrm{~cm})$ on an elevated mesh floor. Calibrated von Frey filaments (Bioseb) were applied to the plantar surface of each hindpaw until they just bent in a series of ascending forces up to the mechanical threshold. Filaments were tested five times per paw and the paw withdrawal threshold (PWT) was defined as the lower of two consecutive filaments for which three or more withdrawals out of the five trials were observed (Benbouzid et al., 2008a; Bohren et al., 2010; Yalcin et al., 2014).

\section{Treatment procedures}

Long-term and acute drug treatment experiments were conducted on independent sets of mice. The long-term treatment with antidepressants began at least 2 weeks after the surgical procedure (cuff implantation or sham surgery). Duloxetine (Interchim, D4223) and amitriptyline (Sigma-Aldrich) were delivered p.o. $(200,150,100$, or $50 \mu \mathrm{g} / \mathrm{ml})$ through the drinking water with ad libitum access as sole source of fluid. The drugs were dissolved in water with $0.2 \%$ saccharin to increase palatability and control mice were given a solution of $0.2 \%$ saccharin in water (vehicle solution). To assess the daily dose of antidepressant that was actually received by the animals (in $\mathrm{mg} / \mathrm{kg} / \mathrm{d}$ ), the bottles containing the treatment were weighed daily and we calculated the ratio between the intake amount of antidepressant per cage and the weight of the animals. For acute administration, duloxetine or amitriptyline was usually dissolved in water with $0.2 \%$ saccharin and administered p.o. $(15,20$, or $30 \mathrm{mg} / \mathrm{kg}$, $10 \mathrm{ml} / \mathrm{kg}$ ) with feeding needles (Cadence Science, 7921) except for noradrenergic lesion experiments, for which amitriptyline was administered intraperitoneally $(15 \mathrm{mg} / \mathrm{kg}, 5 \mathrm{ml} / \mathrm{kg})$, dissolved in $0.9 \% \mathrm{NaCl}$. Yohimbine (20 $\mu \mathrm{g} / \mathrm{ml}$; Sigma-Aldrich), an antagonist of $\alpha_{2}$ adrenoceptors, and 


\section{A}

Experimental design:

- for dose-response experiments

(Figs. 2 and $10 \mathrm{~A}-\mathrm{C}$ ),

experiments using transgenics mice

(Figs. 4 E-F, 5 A and D, 10 F-G)

- for sampling

\section{C}

Experimental design:

- for acute antidepressant experiments using siRNA

(Figs. 4 B-C)

B

- for lesion experiments

(Figs. 3, 10D)

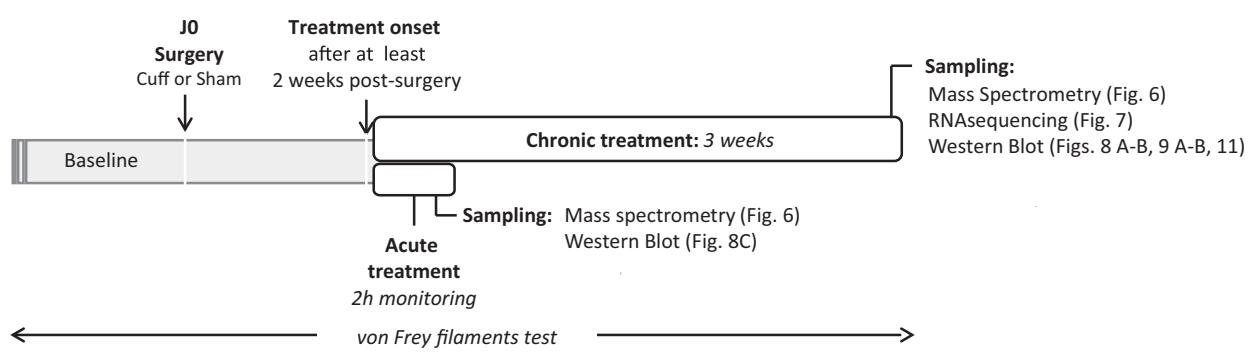

Experimental design:

- for sampling at end of the experiments

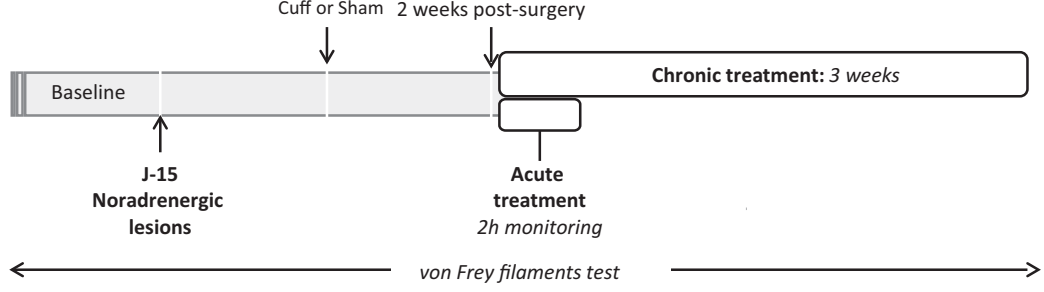

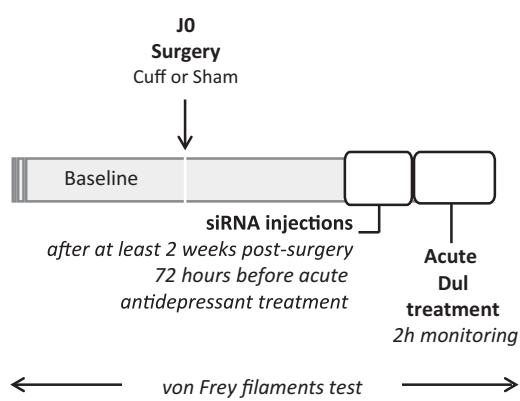

D

Experimental design:

- for acute antidepressant experiments

using various antagonists

(Figs. 4A, 5B, 10E)

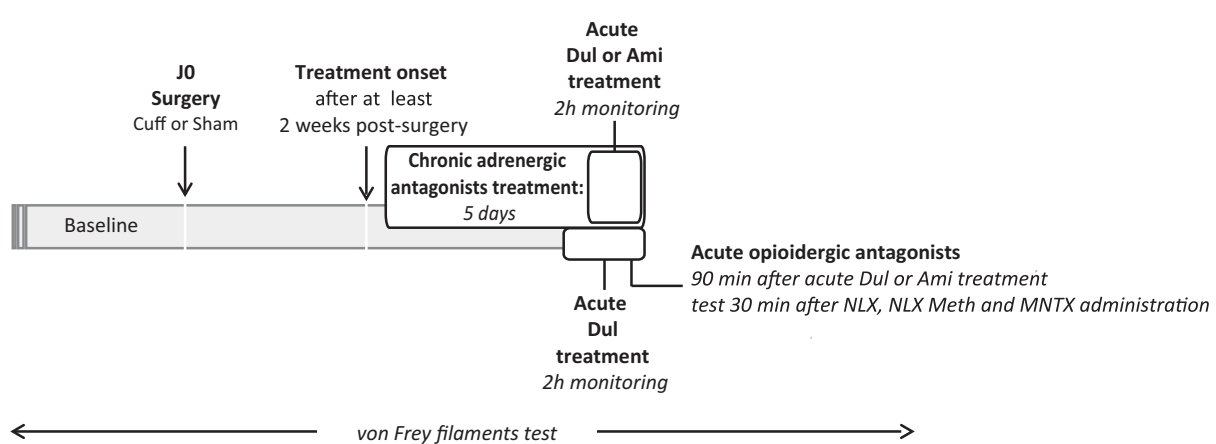

\section{E}

\section{Experimental design:}

- for chronic antidepressant experiments using various antagonists

(Figs. 4D, 5C, 10H)

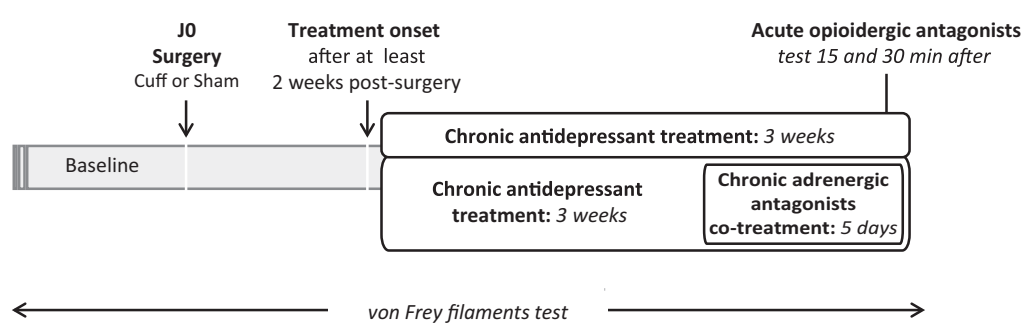

Figure 1. Time course of experiments. For all experiments, the baseline mechanical threshold was assessed with von Frey filaments before the surgical procedure (cuff implantation or sham surgery). The treatments began at least 2 weeks after this surgical procedure. $A$, Experimental design for dose-response experiments, studies in transgenic mice, and morphological or molecular analyses (mass spectrometry, RNA sequencing, Western blot). B, Experimental design for lesion experiments. C, Experimental design for siRNAs' effect on acute antidepressant action. $\boldsymbol{D}$, Experimental design for antagonists' effect on acute antidepressant action. NLX, Naloxone; NLX Meth, naloxone methiodide; MNTX, methylnaltrexone. $\boldsymbol{E}$, Experimental design for antagonists' effect on chronic antidepressant action. Dul, Duloxetine; Ami, amitriptyline. 
propranolol (50 $\mu \mathrm{g} / \mathrm{ml}$; Sigma-Aldrich), a nonselective antagonist of $\beta$ adrenoceptors, were delivered p.o. through the drinking water. Mice received these antagonists for $5 \mathrm{~d}$ starting 2 weeks after the beginning of the long-term treatment in cotreatment with duloxetine or vehicle for chronic experiments or for $5 \mathrm{~d}$ before acute administration of duloxetine for acute experiments. The injection of naloxone methiodide (NLX Meth, $5 \mathrm{mg} / \mathrm{kg}$, s.c.; Sigma-Aldrich), a nonselective antagonist of opioid receptors which does not cross the blood-brain barrier, was performed after $25 \mathrm{~d}$ of duloxetine or amitriptyline treatment or $90 \mathrm{~min}$ after the acute administration of duloxetine. The injection of naloxone, a nonselective antagonist of opioid receptors (NLX, $1 \mathrm{mg} / \mathrm{kg}$, s.c.; SigmaAldrich), and of methylnaltrexone, a nonselective antagonist of opioid receptors that cannot cross the blood-brain barrier (MNTX, $10 \mathrm{mg} / \mathrm{kg}$, s.c.; Sigma-Aldrich), were done $90 \mathrm{~min}$ after the acute administration of duloxetine. To inhibit the NF- $\kappa$ B pathway, mice received two injections per day (morning and evening) of pyrrolidine dithiocarbamate (PDTC, $20 \mathrm{mg} / \mathrm{kg}, 5 \mathrm{ml} / \mathrm{kg}$, i.p.; Sigma-Aldrich) dissolved in $0.9 \% \mathrm{NaCl}$ solution that was also used for control injections. Treatment with the anti-TNF- $\alpha$ drugs adalimumab (Humira, AbbVie, $1 \mathrm{mg} / \mathrm{kg}$ ) or certolizumab pegol (Cimzia, UCB, $6 \mathrm{mg} / \mathrm{kg}$ ) began 15 days after the nerve injury and was maintained for 17 days. During anti-TNF- $\alpha$ treatment, the mice received 1 injection every $4 \mathrm{~d}$ then every $2 \mathrm{~d}$ (morning). Drugs were dissolved in $0.9 \% \mathrm{NaCl}$ solution that was also used for control injections and they were administered subcutaneously in a volume of $5 \mathrm{ml} / \mathrm{kg}$. For in vivo anti-Toll-like receptor 2 (TLR2) experiments, mice were treated with TLR2 and TLR4 antagonist RS-LPS $(0.1 \mathrm{mg} / \mathrm{kg}, 5 \mathrm{ml} / \mathrm{kg}$ in $0.9 \% \mathrm{NaCl}$, i.p.; InvivoGen) twice a day for 1 week or with neutralizing anti-TLR2 antibody (T2.5, $2 \mu \mathrm{g}$ per mouse, i.v. retroorbitally; InvivoGen) every $4 \mathrm{~d}$ and then every $2 \mathrm{~d}$ for 15 days. For cellular and molecular experiments, dorsal root ganglia and/or blood were collected at selected time after acute administration or after 3 weeks of chronic treatment.

\section{Noradrenergic lesions}

To test the role of central and peripheral noradrenergic systems in the therapeutic action of antidepressants, we performed lesions of the noradrenergic system. Chemical peripheral noradrenergic lesion was performed 2 weeks before nerve injury using guanethidine monosulfate (Sigma-Aldrich) with 5 daily intraperitoneal injections $(30 \mathrm{mg} / \mathrm{kg}, 5 \mathrm{ml} /$ $\mathrm{kg}$ ). For chemical denervation of spinal noradrenergic terminals, mice were injected intrathecally, with 6-hydroxydopamine (6-OHDA; $20 \mu \mathrm{g}$ per mouse, in $5 \mu \mathrm{l}$ of $0.9 \% \mathrm{NaCl}$ solution containing $100 \mu \mathrm{g} / \mathrm{ml}$ ascorbic acid) under ketamine $(68 \mathrm{mg} / \mathrm{kg}) / x y l a z i n e ~(10 \mathrm{mg} / \mathrm{kg})$ intraperitoneal anesthesia. For this intrathecal thoracic administration, the animal was anesthetized, the skin of the back was shaved, and a $1 \mathrm{~cm}$ incision was made near the insertion of the lower rib. A 27-gauge needle connected to a $50 \mu \mathrm{l}$ Hamilton syringe was inserted into the intervertebral space between the thoracic T12 and lumbar L1 vertebrae. After the injection, the needle was removed and the skin was sutured. A control group of nonlesioned mice underwent the same procedure as the lesioned groups. At end of the experiments (i.e., 5 weeks after sciatic nerve surgery), nerveinjured and sham mice were deeply anesthetized with pentobarbital and perfused intracardially with $4 \%$ paraformaldehyde in phosphate buffer $0.1 \mathrm{M}(10 \mathrm{ml} / \mathrm{min})$. Lumbar dorsal root ganglia (L4, L5, and L6) and spinal cord were dissected, postfixed, cryoprotected, embedded in optimal cutting temperature compound (Sakura Finetek), frozen, and cut into $14-\mu \mathrm{m}$-thick sections that were mounted on SuperfrostPlus slides (Kindler). To evaluate tyrosine hydroxylase $(\mathrm{TH})$ expression, we used standardized procedures (Kaufling et al., 2010), incubating the sections with a sheep anti-TH antibody (1:1000; Millipore, AB1542). The sections were then incubated with secondary Cy3-conjugated donkey antibodies (1:300; Jackson ImmunoResearch, 713-165-147). Sections were washed, mounted with Vectashield, and viewed under a Nikon E80i microscope with $10 \times$ and $20 \times$ objectives and images were acquired with an MBF Bioscience camera CX9000 using Picture Frame acquisition software. A separate set of animals with central or peripheral lesions was also studied to control for noradrenaline and dopamine levels in the lumbar spinal cord (see "Catecholamine quantification in the lumbar spinal cord" section below).

\section{Tissue and blood collection for molecular analysis}

In separate experiments, dorsal root ganglia and/or lumbar spinal cord were collected either after 3 weeks of chronic oral antidepressant treatment or $120 \mathrm{~min}$ after acute administration of duloxetine for acute experiments. Mice were killed by cervical dislocation, the back was dissected, and a midline incision was done in the lumbar vertebrae to extract the L4, L5, and L6 dorsal root ganglia ipsilateral to the surgery and the lumbar spinal cord from L3 to L6. The three dorsal root ganglia were pooled per animal and all tissue was quickly frozen and stored at $-80^{\circ} \mathrm{C}$ until protein or RNA extraction.

For plasma assays of duloxetine, intracardiac blood collection was performed in mice under deep general anesthesia (ketamine $68 \mathrm{mg} / \mathrm{kg}$ / xylazine $10 \mathrm{mg} / \mathrm{kg}$, i.p.) by inserting a needle in the left ventricle. Blood was then collected and placed in blood collection tubes (Vacutainer, BD Biosciences, $4 \mathrm{ml}$, \#367526). The samples were then centrifuged $(1500 \times \mathrm{g}$, $20^{\circ} \mathrm{C}, 15 \mathrm{~min}$ ) and the plasma was collected and frozen at $-80^{\circ} \mathrm{C}$.

\section{Plasmatic levels of duloxetine}

To compare duloxetine concentrations in neuropathic pain patients and in the animal model, plasma levels were measured in animals either under chronic duloxetine treatment or at $1,2,5,10$, or $24 \mathrm{~h}$ after acute administration.

The human study received institutional ethics approval from the Hôpitaux Universitaires de Strasbourg (France) and was performed in accordance with the Declaration of Helsinki and its subsequent amendments, good clinical practice, and all applicable regulatory requirements. All patients provided written informed consent before their participation in the study. The patients were identified by numbers.

The primary purpose was to evaluate residual plasmatic concentration of duloxetine (i.e., before the morning intake) in patients relieved of at least $30 \%$ of their neuropathic pain with duloxetine treatment (V0 visit). The secondary purpose was to measure the plasmatic peak concentration (i.e., $6 \mathrm{~h}$ after the morning intake; V1 visit) (Senthamil Selvan et al., 2007) in the same patients.

At V0, the neuropathic characteristic of the pain was assessed with the DN4 questionnaire (Bouhassira et al., 2005) and the etiology and location of neuropathic pain was determined. The pain intensity reported by the patient on a numeric rating scale with 11 points (Jensen and Karoly, 1992) was evaluated during the medical visits (V0 and V1) and concerned the following: recall of pain intensity before the start of duloxetine treatment, pain intensity experienced just before or when taking duloxetine at $\mathrm{V} 0$, and pain intensity experienced $6 \mathrm{~h}$ after taking duloxetine at V1. Sensation of improvement experienced by the patient was assessed on a Patient Global Impression of Change in 7 points scale (Dworkin et al., 2005). Patients' inclusion criteria were as follows: treated with Cymbalta (60 mg daily in one intake) for peripheral diabetic neuropathic pain or for depression and associated with pain identified as neuropathic, reporting relief of at least $30 \%$ of their neuropathic pain since the initiation of treatment, affiliated to a social security system, and having signed an informed consent. Exclusion criteria were as follows: concomitant treatment with enoxacin, fluvoxamine, flecainide, propafenone, metoprolol, risperidone, verapamil, omeprazole, modafinil, mequitazine, tamoxifen, and IMAO; necessary information could not be given to the patients; pregnant or nursing women; nonmenopausal woman without effective contraception; and patient under judicial protection, guardianship, or curatorship. A total of eight patients were included.

\section{Plasma and tissue measurements}

Duloxetine quantification in the plasma of humans and animals. To compare duloxetine concentrations in neuropathic pain patients and in the animal model, plasma levels were measured by mass spectrometry. 10 pmol of D3-duloxetine internal standard (in which 3 atoms of hydrogen ${ }^{1} \mathrm{H}$ have been substituted by 3 atoms of deuterium ${ }^{2} \mathrm{H}$; Alsachim) were added to $200 \mu \mathrm{l}$ of lithium-heparin plasma. Plasmas were acidified up to $2.5 \% \mathrm{v} / \mathrm{v}$ with formic acid (final volume of $800 \mu \mathrm{l}$ ). After centrifugation $\left(20,000 \times g, 20^{\circ} \mathrm{C}, 15 \mathrm{~min}\right)$, the supernatant was submitted to a solid phase extraction (SPE) using a positive pressure manifold (Thermo Electron). OASIS HLB SPE-cartridges $\left(1 \mathrm{~cm}^{3}, 30 \mathrm{mg}\right.$; Waters $)$ were first activated with $1 \mathrm{ml}$ of acetonitrile (ACN) and then washed with $1 \mathrm{ml}$ of 
$\mathrm{H}_{2} \mathrm{O} /$ formic acid $0.1 \%(\mathrm{v} / \mathrm{v})$. The samples were loaded and the SPE cartridges were washed with $1 \mathrm{ml}$ of $\mathrm{H}_{2} \mathrm{O} /$ formic acid $0.1 \%$ followed by $1 \mathrm{ml}$ of ACN 5\%/formic acid 0.1\% (v/v/v). The elution was performed with $500 \mu \mathrm{l}$ of $\mathrm{ACN} 50 \% / \mathrm{H}_{2} \mathrm{O}(\mathrm{v} / \mathrm{v})$. Finally, eluted fractions were dried under vacuum before MS analysis (see below).

Catecholamine quantification in the lumbar spinal cord. To control the impact of the lesion procedures on catecholamines in the spinal cord, we also quantified in a set of animals the noradrenaline and dopamine levels in the lumbar spinal cord using mass spectrometry. Lumbar spinal cord samples were homogenized with a tissue mixer (Bio-Gen PRO200 Homogenizer equipped with a $7 \mathrm{~mm}$ saw-tooth generator probe) in $200 \mu \mathrm{l}$ of $0.5 \mu \mathrm{M}$ ascorbic acid. Homogenates were sonicated $10 \mathrm{~s}$ at $90 \mathrm{~W}$ and centrifuged $\left(18,000 \times g, 4^{\circ} \mathrm{C}, 15 \mathrm{~min}\right)$. Supernatant was recovered and the concentration of proteins was determined (protein assay; Bio-Rad). Then, $10 \mu \mathrm{l}$ of the extract was derived with the AccQ-Tag Ultra Derivatization kit (Waters) according to the manufacturer. Briefly, $10 \mu \mathrm{l}$ of samples were mixed with $35 \mu \mathrm{l}$ of the kit's borate buffer and $10 \mu \mathrm{l}$ of internal standards (10 pmol/standard; D4-dopamine, C6-noradrenaline; Sigma-Aldrich and Alsachim). D4-dopamine corresponds to an internal standard in which 4 atoms of hydrogen $\left({ }^{1} \mathrm{H}\right)$ have been substituted by 4 atoms of deuterium $\left({ }^{2} \mathrm{H}\right)$. C6-noradrenaline corresponds to an internal standard in which 6 atoms of carbon $\left({ }^{12} \mathrm{C}\right)$ have been substituted by 6 atoms of ${ }^{13} \mathrm{C}$. Then, $10 \mu \mathrm{l}$ of AccQtag reagent was added and the reaction medium was shaken $10 \mathrm{~min}$ at $55^{\circ} \mathrm{C}$. After centrifugation $(20,000 \times g$, $20^{\circ} \mathrm{C}, 5 \mathrm{~min}$ ), supernatant was subjected to a LC-MS/MS analysis.

\section{LC-MS/MS instrumentation and analytical conditions}

$\mathrm{LC}$ analyses were used to determine the presence of duloxetine or catecholamines using the multiple reaction monitoring mode (MRM). Analyses were performed on a Dionex Ultimate 3000 HPLC system (Thermo Scientific) coupled with an Endura triple quadrupole mass spectrometer (Thermo Electron). The system was controlled by Xcalibur version 2.0 software (Thermo Electron). Dried samples (spinal cord extracts) were suspended in $100 \mu \mathrm{l}$ of $\mathrm{H}_{2} \mathrm{O} /$ formic acid $0.1 \%$ (v/v) and $10 \mu \mathrm{l}$ of the solution was loaded onto an Accucore RP-MS column (ref 17626$102130 ; 100 \times 2.1 \mathrm{~mm} 2.6 \mu \mathrm{m}$; Thermo Electron) heated at $35^{\circ} \mathrm{C}$. For derived samples, $10 \mu \mathrm{l}$ of the derivatization mixture was analyzed. Elutions were performed by applying linear gradient of mobile phase A/B. Mobile phase A corresponded to $\mathrm{H}_{2} \mathrm{O} 99.9 \%$ /formic acid $0.1 \%(\mathrm{v} / \mathrm{v})$, whereas mobile phase B was ACN 99.9\%/formic acid 0.1\% (v/v). A linear gradient of $20-85 \%$ of mobile phase B at $400 \mu \mathrm{l} / \mathrm{min}$ over $2.5 \mathrm{~min}$ was applied followed by a washing step ( $0.5 \mathrm{~min}$ at $85 \%$ of mobile phase B) and an equilibration step ( $1 \mathrm{~min}$ of $20 \%$ mobile phase B).

The MRM mode was performed at $3500 \mathrm{~V}$ of liquid junction voltage and $292^{\circ} \mathrm{C}$ capillary temperature. The selectivity for both quadripoles Q1 and Q3 was set to $0.7 \mathrm{Da}$, which is the full width at half maximum of peak height. The collision gas pressure of quadripole Q2 (collision chamber) was set at 2 mTorr of argon. The selection of the monitored transitions and the optimization of the collision energy (CE) were manually determined. In MRM mode, two mass analyzers (quadripoles Q1 and Q3) were used as static mass filters to select particular precursor ions (parent ions selected in quadripole Q1) and to monitor the particular fragments (daughter ions, detected in quadripole Q3) produced after fragmentation in the collision chamber (quadripole Q2).

The respective parent ions, transitions and corresponding CE used for MRM are as follow: for duloxetine, $\mathrm{m} / z 298.25 \rightarrow \mathrm{m} / z$ 123.75 (CE $=42$ $\mathrm{eV}), \mathrm{m} / z 298.25 \rightarrow \mathrm{m} / z 155.24(\mathrm{CE}=23 \mathrm{eV})$ and $\mathrm{m} / z 298.25 \rightarrow \mathrm{m} / z$ $183.17(\mathrm{CE}=28 \mathrm{eV})$; for D3-duloxetine, $\mathrm{m} / z 301.25 \rightarrow \mathrm{m} / z 123.75$ $(\mathrm{CE}=40 \mathrm{eV}), \mathrm{m} / z 301.25 \rightarrow \mathrm{m} / z 157.12(\mathrm{CE}=7 \mathrm{eV})$ and $301.25 \rightarrow \mathrm{m} / z$ $183.05(\mathrm{CE}=27 \mathrm{eV})$; for AccQtag-dopamine, $\mathrm{m} / z 324.25 \rightarrow \mathrm{m} / z 171.10$ $(\mathrm{CE}=33 \mathrm{eV})$; for AccQtag-D4-dopamine, $\mathrm{m} / z 328.25 \rightarrow \mathrm{m} / z 171.10$ $(\mathrm{CE}=35 \mathrm{eV})$; for AccQtag-noradrenaline, $\mathrm{m} / z \quad 340.25 \rightarrow \mathrm{m} / z$ $171.25(\mathrm{CE}=35 \mathrm{eV})$; for AccQtag-C6-noradrenaline, $\mathrm{m} / z 346.25 \rightarrow \mathrm{m} / z$ $171.25(\mathrm{CE}=27 \mathrm{eV})$.

The identification of the compounds was based on precursor ion, selective fragment ions, and retention times obtained for duloxetine or derived-catecholamine and the corresponding internal standard. Absolute quantifications of the compounds were done using the ratio of daughter ions response areas on the internal standards (isotope dilution method).

\section{siRNA experiments}

$\alpha_{2}$ adrenoceptor subtypes involved in acute effects of duloxetine were identified using siRNA-mediated knock-down of adra2a and adra2c. Knock-down of adra2a and adra2c mRNA were performed using ACCELL siRNA (catalog \#E-049576-00 and \#E-043744-00, respectively) designed and validated by Thermo Fisher/Dharmacon. A nontargeting siRNA (catalog \#D-001910-10-05) was used as a negative control. Stock solutions for the targets and scrambled siRNA were prepared at $100 \mu \mathrm{M}$ in $1 \times$ siRNA buffer (diluted from Dharmacon $5 \times$ siRNA buffer, catalog \#B-002000-UB-100). Targets and scrambled negative siRNA were injected intrathecally (10 $\mu \mathrm{l}$ per mouse) under gaseous anesthesia (isoflurane $1.5-2 \%)$. Briefly, for lumbar intrathecal administration, a 27 -gauge needle connected to a $50 \mu \mathrm{l}$ Hamilton syringe was inserted between the L5 and L6 vertebrae into the subarachnoidal space. Placement of the needle was verified by the elicitation of tail flick movement. Time course study was done with qRT-PCR to identify optimal time points for assessing knock-down.

\section{$q R T-P C R$}

To verify the selectivity of the siRNAs, we quantified the expression of the subtypes of the $\alpha_{2}$ adrenoceptors' genes (adra2a, adra2b, and $a d r a 2 c$ ) in lumbar spinal cord by qRT-PCR. Total mRNA was extracted using the RNAeasy kit (Qiagen) and the cDNA was generated using the iScript cDNA synthesis kit from Bio-Rad. qRT-PCR was performed on a Thermocycler MylQ (Bio-Rad) using the Bio-Rad IQ Syber Green Supermix assay. PCR consisted of an initialization step at $95^{\circ} \mathrm{C}$ for $3 \mathrm{~min}$ and the amplification was realized for 40 cycles with denaturation at $95^{\circ} \mathrm{C}$ for $20 \mathrm{~s}$, followed by annealing at $95^{\circ} \mathrm{C}$ for $20 \mathrm{~s}$, and an extension at $60^{\circ} \mathrm{C}$ for $20 \mathrm{~s}$. All experiments were performed in duplicate sample deposits on the amplification plate. The relative abundance of each RNA target gene transcript was normalized using endogenous control genes hypoxanthineguanine phosphoribosyltransferase (HPRT) and glyceraldehyde phosphate dehydrogenase (GAPDH). Data were analyzed according to the standard curve method. Primers have been designed using Oligo6.0 and M-fold softwares based on Mus musculus mRNA sequences available in the NCBI database and were as follows: musADRA2afw, CCAAGCTGCAAGATCAACGA and musADRA2arev, TACGCACGTAGACCAGGATC; musADRA2bfw, CAGAAGAAGGGGACTAGTGGG and musADRA2brev, GGCAGT GTTTGGGGTTCACAT; musADRA2cfw, CCTACTGGTACTTCG GGCAA and musADRA2crev, CCAGTAGCGGTCCAGACTAA.

\section{Immunoblot analysis}

To further explore the TNF- $\alpha-\mathrm{NF}-\kappa \mathrm{B}$ pathway, whose gene expression was globally enhanced in the dorsal root ganglia following nerve injury and downregulated by chronic duloxetine treatment, we used the Western blot technique. Total proteins were extracted in $150 \mu \mathrm{l}$ of lysis buffer (20 mm Tris pH 7.5; 150 mm NaCl; 10\% glycerol; 1\% NP-40; Protease Inhibitor Cocktail; Roche), quantitated with Bio-Rad Protein Assay Dye Reagent Concentrate and stored in Laemmli buffer (2\% SDS; $25 \%$ glycerol; $0.01 \%$ bromophenol blue; $0.125 \mathrm{M}$ Tris, $\mathrm{pH} 6.8$ ). Ten micrograms of total protein from individual animals were resolved by $12 \%$ SDS-PAGE under reducing conditions and then transferred to PVDF membrane (Immobilon transfer membranes; Millipore, IPVH00010). The blots were incubated for $1 \mathrm{~h}$ in blocking agent (ECL kit, GE Healthcare) overnight with antibodies specific for TNF- $\alpha$ (1:500, R\&D Systems, AF-410-NA), TRAF family member-associated NF- $\kappa$ B activator (TANK) (1:1000; Cell Signaling Technology, 2141), TLR2 (1:500; Abcam, ab108998), C-C motif chemokine receptor like 2 (CCRL2) (1:500, Thermo Fisher Scientific, PA28743), or $\beta$-tubulin (1:50000; Abcam, ab108342), followed by rabbit anti-goat horseradish peroxidase (HRP)-conjugated secondary antibodies (1:12000; Abcam, ab97100) or goat anti-rabbit HRP-conjugated secondary antibodies (1:10000; Millipore, AP307P), respectively. Blots were revealed by chemiluminescence (ECL Prime Western Blotting Detection Reagent, GE Healthcare, RPN 2232) using Hyperfilm (GE Healthcare, RPN 1674K). Relative protein expression was determined using the densitometry tool of Adobe Photoshop CS5 software. The bands were evaluated in grayscale, the background value was subtracted, and the ratio 
between the considered protein and $\beta$-tubulin was calculated for each sample.

\section{RNA sequencing ( $R N A-S e q)$}

To go further in understanding the peripheral component of duloxetine action, we conducted a transcriptomic analysis on dorsal root ganglia using RNA-Seq.

\section{Sample collection}

Total RNA was extracted from dorsal root ganglia tissues with the Qiagen RNeasy Mini Kit according to the manufacturer's instructions. The quality of samples was verified using a bioanalyzer (Agilent Technologies, 2100), which uses a microcapillary-based electrophoretic cell, allowing rapid and sensitive investigation of nucleic acid samples. The samples were considered to be of high quality when their absorbance ratio 260/ 280 was between 1.8 and 2 . The stringent RNA quality was also controlled using the bioanalyzer. The samples used for sequencing showed only two distinct peaks for $18 \mathrm{~S}$ and $28 \mathrm{~S}$ rRNAs, with a ratio of $\sim 2$ and an RNA integrity number $>7.8$. (Schroeder et al., 2006).

\section{Library preparation and sequencing}

RNA-Seq (Wang et al., 2009) libraries of polyadenylated RNAs were prepared using Illumina TruSeq chemistry and were sequenced in paired-end mode. For each sample, 250 ng of total RNA was used for library preparation. Next-generation sequencing library preparation was performed on the Beckman Biomek FX using the Illumina TruSeq RNA Sample Preparation Kit version 2 and the Illumina TruSeq LT DNA adapters according to manufacturer's protocol (TruSeq RNA Sample Preparation version 2 Guide) at the EMBL Genecore. The procedure included the isolation and fragmentation of polyadenylated RNA, synthesis of double-stranded cDNA, end repair, A-tailing, and ligation of sequencing adaptors and a final PCR amplification step. Resulting RNASeq libraries were sequenced on an Illumina Hiseq2500 at a read length of $50 \mathrm{bp}$ in paired-end mode. RNA-Seq was performed for $n=3$ biological replicates per group.

\section{Bioinformatics analyses}

The bioinformatic processing of RNA-Seq data was done as described previously (Maussion et al., 2015; Farmer et al., 2016; Lutz et al., 2017) using the FASTX-Toolkit (http://hannonlab.cshl.edu/fastx_toolkit/ links.html) and Trimmomatic (Bolger et al., 2014) for adapter trimming from raw read sequences; Bowtie2 and TopHat2 (Trapnell et al., 2009) for alignment of trimmed reads to the reference mouse genome; HTSeqcount for gene counting; and DESeq2 (Love et al., 2014) for differential expression analysis.

Alignment. Following the high-throughput sequencing, $50 \mathrm{bp}$ paired-end reads were aligned to the mouse reference genome (mm10) using Bowtie2 and TopHat version 2.1.0 (http://ccb.jhu.edu/ software/tophat/index.shtml) with the following parameters: a mate insert distance of $75 \mathrm{bp}$ and a fr-unstranded library type because our library preparation protocol does not conserve information regarding strand (see illumina.com/documents/products/technotes/ RNASeqAnalysisTopHat.pdf). The reads that reached mapping quality of 50 under the TopHat 2 software (i.e., that map to a unique location in the reference genome) were used for gene quantification.

Quantification. Genes were first annotated based on the Ensembl annotation database (Ensembl release 75, GRCm38). To quantify gene expression level, we then used HTSeq-count version 0.6.1p1 (http://htseq. readthedocs.io/en/release_0.10.0/) to count the number of reads that overlapped the genes identified in the aforementioned annotation (Anders et al., 2015). To attribute or not each read to a given gene, including when overlaps with two genes were present, we used HTSeq-count under the intersection-nonempty mode (https://htseq. readthedocs.io/en/master/count.html). The results were then combined to form a count matrix, providing expression level for each gene in each biological sample.

Differential expression analysis. Genes with an absence of mapped read were removed from the analysis. Furthermore, genes with low counts were also removed from the analysis by keeping only those that had at least 20 counts per sample in average. The differential expression analysis to compare expression level between experimental groups was performed using the DESeq2 generalized linear model to conduct pairwise comparisons (e.g., saccharin-cuff/saccharin-sham, duloxetine-cuff/saccharin-cuff, etc.).

For functional analyses, we used the DAVID website (DAVID Bioinformatics Resources 6.7, National Institute of Allergy and Infectious Diseases-National Institutes of Health; https://david.ncifcrf.gov/), and the Gene Set Enrichment Analysis software (GSEA, version 2.2.0, The Broad Institute/Massachusetts Institute of Technology). The DAVID Bioinformatics Resources was one of the earliest bioinformatics tools for functional analyses of large gene lists, which are usually obtained from genome-wide studies (da Huang et al., 2009). It relies on the focus on specific sets of genes; that is, groups of genes that are known to share common biological function. However, such analysis is based on the list of genes displaying significant expression changes, which is dependent upon the significance threshold chosen for differential expression (here, $p<0.01)$. GSEA is another analytical method for interpreting gene expression data by using their ranking as a function of fold changes across experimental groups (upregulation/downregulation) (Subramanian et al., 2005). The GSEA method is independent from the choice of a significance threshold, and makes it possible to calculate an enrichment score (ES) that reflects the degree of overrepresentation of a group of genes that belong to a specific signaling pathway and are enriched in down- or upregulated genes.

\section{Experimental design and statistical analysis}

The global design of all experiments is described in Figure 1. Data were collected in a blinded manner to avoid bias. Minimum sample sizes were estimated from previously published datasets with similar experimental parameters. All statistical tests, except for genomic analyses, were performed using STATISTICA 12 software (Statsoft). Sigma-Plot 12.5 software (Systat Software) was used to generate the graphs. Results in all graphs are presented as mean \pm SEM. Individual data were overlapped on bar graphs concerning duloxetine dosage (see Fig. 6) and immunoblotting (see Figs. 8, 9, 11).

Behavioral experiments. Experiments were conducted either in males only (see Figs. 2, 3, $4 A-D, 5 B, C, 6 A, 8 D-F, 9 C, 10 A-E, H$ ) or in an equal number of males and females per experimental group (see Figs. $4 E, F$, $5 A, D, 10 F, G)$. The numbers of animals in each experimental group is provided both in graphs (in brackets) and in the extended data tables supporting each figure. Statistical analyses for behavioral studies were performed using multifactor ANOVA. The surgery procedure (sham or cuff) and the various treatments were taken as between-group factors. When needed, the time of measurement was taken as a within-subject factor. The Duncan test was used for post hoc comparisons. For the comparison of mechanical sensitivity thresholds before and after noradrenergic antagonist (see Figs. 4A, D, 10E) or opioidergic antagonist (see Fig. $5 B$ ) and siRNA (see Fig. $4 C$ ) administrations in duloxetine-related experiments, we used one-way ANOVA and the Duncan test for post hoc comparisons. The significance level for all aforementioned analyses was set at $p<0.05$ and the exact $p$-values are provided down to 0.001 . Detailed information on the number and sex of animals in each experimental group, the statistical tests that were used, and the statistical results is given in the extended data tables that support each figure (Fig. 2-1, available at https://doi.org/10.1523/JNEUROSCI.1004-18.2018.f2-1; Fig. 3-1, available at https://doi.org/10.1523/JNEUROSCI.1004-18.2018.f3-1; Fig. 4-1, available at https://doi.org/10.1523/JNEUROSCI.1004-18.2018.f4-1; Fig. 5-1, available at https://doi.org/10.1523/JNEUROSCI.1004-18.2018.f5-1; Fig. 8-1, available at https://doi.org/10.1523/JNEUROSCI.1004-18.2018.f8-1; Fig. 9-1, available at https://doi.org/10.1523/JNEUROSCI.1004-18.2018.f9-1; and Fig. 10-1, available at https://doi.org/10.1523/JNEUROSCI.1004-18.2018.f10-1).

Dosage, immunoblotting, and $q R T-P C R$ experiments. Behavioral readout of the experiments was evaluated before sampling for data reported in Figures $3,6,8,9$, and 11. Experiments were conducted in males for Figures $3 B$, $4 B, 6,8 A, C, F, 9 A, B$, and 11 and in females for Figure $8 B$. The numbers of animals in each experimental group is provided both in graphs (in brackets) and in the extended data tables supporting each figure. After calculating the ratio between the target protein and $\beta$-tubulin, immunoblotting data for each animal was expressed as the fold change from the mean of the corresponding control group (see Figs. 8, 9, 11) and statistical analyses were per- 

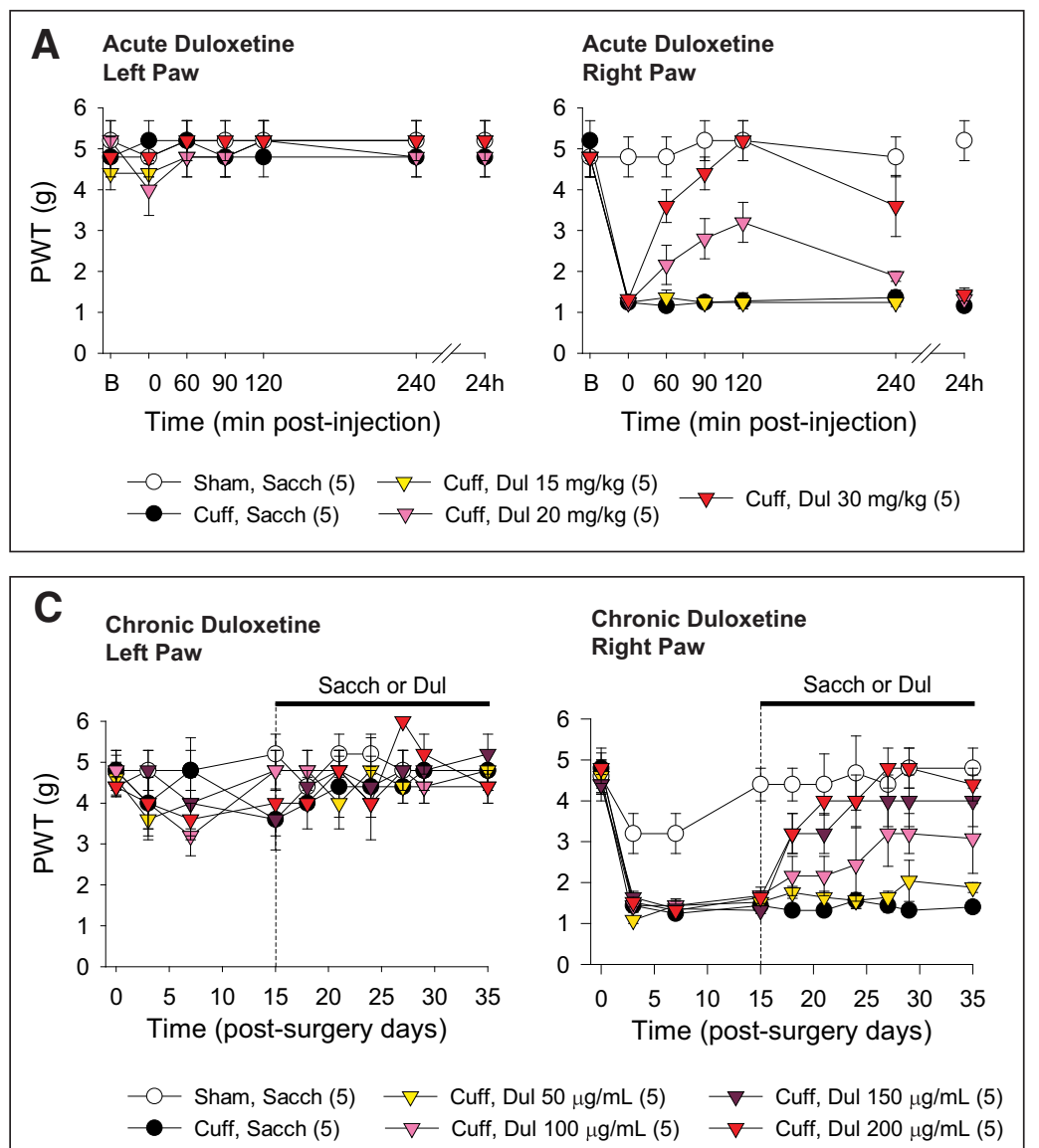

\section{B Acute Duloxetine Sham (right paw)}

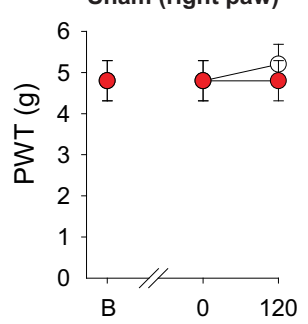

Time (min post-injection)

$$
\begin{aligned}
& \text {-1 Sham, Sacch (5) } \\
& -0 \text { Sham, Dul } 30 \mathrm{mg} / \mathrm{kg}(5)
\end{aligned}
$$

\section{Chronic Duloxetine Sham (right paw)}

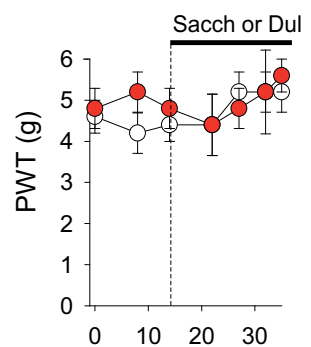

Time (post-surgery days)

-O- Sham, Sacch (5)

- - Sham, Dul $200 \mu \mathrm{g} / \mathrm{mL}$ (5)
$\mathbf{E}$

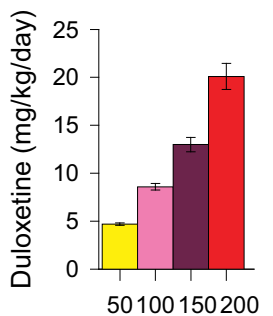

(5) (5) (5) (5)

Dul $(\mu \mathrm{g} / \mathrm{mL})$

Figure 2. Characterization of the effect of acute and chronic oral duloxetine treatments on mechanical allodynia in mice. PWTs were assessed using von Frey filaments. Neuropathic pain was induced by inserting a cuff around the main branch of the sciatic nerve at least 2 weeks before the start of duloxetine treatment. $A$, Mice with a cuff around the right sciatic nerve received an acute per os administration of duloxetine (Dul; 15,20 , or $30 \mathrm{mg} / \mathrm{kg}$ ) or water with saccharin (Sacch; $0.2 \%$ ). Duloxetine displayed a transitory and ipsilateral anti-allodynic action at the highest dose $(30 \mathrm{mg} / \mathrm{kg})$. B, The $30 \mathrm{mg} / \mathrm{kg}$ duloxetine did not affect mechanical PWT of sham mice. C, For chronic treatment, duloxetine $(50,100,150$, or $200 \mu \mathrm{g} / \mathrm{ml})$ was delivered in the drinking water with $0.2 \%$ saccharin. This treatment dose-dependently suppressed the cuff-induced mechanical allodynia. No effect of duloxetine was observed on the contralateral paw. $\boldsymbol{D}$, Chronic oral duloxetine (200 $\mu \mathrm{g} / \mathrm{ml})$ had no influence on the PWT of sham mice. $\boldsymbol{E}$, Histogram showing the equivalence between $\mu \mathrm{g} / \mathrm{ml} \mathrm{and} \mathrm{mg} / \mathrm{kg} / \mathrm{d}$ for duloxetine based on fluid consumption from animals with behavioral data displayed in C. For all graphs, data are expressed as mean \pm SEM. $n$ are given in brackets. "B" (for baseline) corresponds to the PWT before surgery, chronic treatment start and duration are indicated by the dotted and the thick lines in $\boldsymbol{C}$ and $\boldsymbol{D}$. Detailed statistics are provided in Figure 2-1, available at https://doi.org/10.1523/JNEUROSCI.1004-18.2018.f2-1.

formed using the nonparametric Kruskal-Wallis test, followed by multiple comparisons with the Wilcoxon test. qRT-PCR data (Fig. 4B) were also analyzed using the nonparametric Kruskal-Wallis test, followed by multiple comparisons with the Wilcoxon test. The relation between duloxetine plasma levels and behavioral response (Fig. 6A) was tested for statistical correlation. The significance level for all aforementioned analyses was set at $p<0.05$ and the exact $p$-values are provided down to 0.001 . Detailed information on the number of animals in each experimental group and their sex, on the statistical tests that was used, and the statistical results, is given in the extended data tables that support each figure (Fig. 4-1, available at https:// doi.org/10.1523/JNEUROSCI.1004-18.2018.f4-1; Fig. 8-1, available at https://doi.org/10.1523/JNEUROSCI.1004-18.2018.f8-1; Fig. 9-1, available at https://doi.org/10.1523/JNEUROSCI.1004-18.2018.f9-1; and Fig. 10-1, available at https://doi.org/10.1523/JNEUROSCI.1004-18.2018.f10-1).

RNA-Seq experiments. Neuropathic pain was induced by inserting a cuff around the main branch of the sciatic nerve. Chronic oral duloxetine treatment started at least 2 weeks after surgery and lasted for 3 weeks. The presence and relief of mechanical allodynia were tested using von Frey filaments. L4, L5, and L6 dorsal root ganglia were collected for molecular analysis. RNA sequencing was performed on $n=3$ biological replicates per group. A differential expression analysis was performed using the DESeq2 generalized linear model to conduct pairwise comparisons with significance level set at $p<0.01$. Statistics for functional analyses were conducted using the DAVID website and using GSEA software and included the multiple testing corrections implemented by each type of software.

\section{Results}

\section{Oral duloxetine displays acute and delayed} anti-allodynic actions

In a model of neuropathic pain induced by sciatic nerve compression (Benbouzid et al., 2008a; Yalcin et al., 2014), we first established the dose-response curve of oral duloxetine leading to an acute antiallodynic action. This acute duloxetine treatment was done at least 2 weeks after the surgical procedure. $20 \mathrm{mg} / \mathrm{kg}$ was necessary to observe partial relief and $30 \mathrm{mg} / \mathrm{kg}$ to reach full relief within $120 \mathrm{~min}$ $\left(F_{(6,120)}=5.5, p<0.001\right)$ (Fig. $2 A$ and Fig. $2-1$, available at https:// doi.org/10.1523/JNEUROSCI.1004-18.2018.f2-1; detailed statistics for all results are given in extended data tables supporting figures). This rapid but transitory allodynia relief was observed in the absence of analgesic action in control animals (Fig. 2B). Although such rapid action is not observed clinically, it could be postulated that the underlying mechanism may recapitulate the one observed after prolonged treatment. We also established a dose-response curve of chronic oral duloxetine provided through drinking water. This chronic duloxetine treatment began at least 2 weeks after the surgical procedure. Under this delivery protocol, allodynia relief required a few days of treatment, with partial effect at $100 \mu \mathrm{g} / \mathrm{ml}$ and full recovery at 150 and $200 \mu \mathrm{g} / \mathrm{ml}\left(F_{(9,216)}=2.9, p<0.001\right)($ Fig. $2 C$ and Fig. 2-1, available at https://doi.org/10.1523/JNEUROSCI.1004- 
18.2018.f2-1). Here again, the allodynia relief was observed in the absence of analgesic action in control animals (Fig. $2 D$ ). The dose necessary to full relief corresponded to $20 \mathrm{mg} / \mathrm{kg} / \mathrm{d}$, with an intake spread over the animal's daily drinking period (Fig. 2E). We then used those acute and prolonged treatment procedures to compare their respective mechanisms.

\section{Acute and prolonged duloxetine treatments recruit distinct sources of noradrenaline}

Clinically, selective serotonin reuptake inhibitors such as fluoxetine are poorly effective against neuropathic pain even though they demonstrate efficacy against depression (Sindrup et al., 2005). This suggests a critical role of the noradrenergic system in pain relief. Here, we tested the respective role of two sources of noradrenaline: the central descending pathways and the peripheral fibers. We selectively lesioned the former by delivering the 6-OHDA toxin intrathecally at thoracic level on the path of descending noradrenergic fibers. This procedure resulted in a loss of TH-positive fibers in the dorsal horn of the spinal cord (Fig. $3 A)$ and a decrease in lumbar noradrenaline $\left(F_{(3,29)}=76.6, p<\right.$ $0.001)$, but not dopamine $\left(F_{(3,29)}=0.4, p=0.74\right)$, levels (Fig. $3 B$ and Fig. 3-1, available at https://doi.org/10.1523/JNEUROSCI.100418.2018.f3-1). Following such lesion, duloxetine lost its capacity to acutely relieve neuropathic allodynia $\left(F_{(2,24)}=13.8, p<0.001\right)$ (Fig. $3 C$ and Fig. 3-1, available at https://doi.org/10.1523/JNEUROSCI.1004-18.2018.f3-1), whereas the delayed anti-allodynic action of chronic duloxetine was preserved $\left(F_{(9,153)}=8.8, p<0.001\right)$ (Fig. 3D and Fig. 3-1, available at https://doi.org/10.1523/ JNEUROSCI.1004-18.2018.f3-1).

The peripheral sympathetic sprouting in the dorsal root ganglia that accompanies peripheral nerve injury (McLachlan et al., 1993; Ramer and Bisby, 1998; Bohren et al., 2013) was suppressed by peripheral injection of guanethidine, a toxin that does not cross the blood-brain barrier and thus spares the central noradrenergic system (Fig. 3A). Although the lesion suppressed noradrenergic sprouting in the dorsal root ganglia, the local $\mathrm{TH}$-expressing neurons (Brumovsky, 2016) that are mostly C-low-threshold mechanoreceptors (and might be dopamine neurons) were not affected by the toxin (Fig. 3A). This lesion of peripheral noradrenergic fibers did not prevent the capacity of acute duloxetine at high dose to rapidly alleviate allodynia $\left(F_{(2,34)}=6.2, p<0.001\right)$ (Fig. $3 C$ and Fig. 3-1, available at https://doi.org/10.1523/JNEUROSCI.1004-18.2018.f3-1), but it abolished the delayed anti-allodynic action of chronic duloxetine $\left(F_{(9,162)}=6.7, p<0.001\right)$ (Fig. $3 D$ and Fig. 3-1, available at https://doi.org/10.1523/JNEUROSCI.1004-18.2018.f3-1). These findings support the idea that different anatomical substrates underlie the acute and delayed actions of duloxetine in a neuropathic pain context.

\section{Acute and prolonged duloxetine treatments recruit different adrenoceptors}

By blocking the reuptake site, duloxetine increases levels of noradrenaline, which then acts on adrenoceptors to exert its effects. The $\alpha_{2}$ adrenoceptor is a family of three receptors, $\alpha_{2 \mathrm{~A}}, \alpha_{2 \mathrm{~B}}$, and $\alpha_{2 \mathrm{C}}$, all products of three different genes. Two of them, $\alpha_{2 \mathrm{~A}}$ and $\alpha_{2 \mathrm{C}}$, are preferentially expressed in the dorsal horn of the spinal cord and implicated in nociceptive controls (Pertovaara, 2006). On the other hand, $\beta_{2}$ adrenoceptors are present on nonneuronal satellite cells of the dorsal root ganglia and have been shown previously to be important to the anti-allodynic action of chronic nortriptyline (Bohren et al., 2013). An antagonist of $\alpha_{2}$ adrenoceptors, yohimbine, prevented acute duloxetine action $\left(F_{(1,16)}=15.3, p<0.001\right)$ (Fig. $4 A$ and Fig. $4-1$, available at
https://doi.org/10.1523/JNEUROSCI.1004-18.2018.f4-1). We then used RNA interference to identify the respective role of $\alpha_{2 \mathrm{~A}}$ and $\alpha_{2 \mathrm{C}}$ in duloxetine action. The selectivity of siRNAs delivered intrathecally was first verified in vivo $\left(\alpha_{2 \mathrm{~A}}-\mathrm{AR}: \mathrm{H}_{2,23}=15.15, p<\right.$ $0.001 ; \alpha_{2 \mathrm{~B}}-\mathrm{AR}: \mathrm{H}_{2,23}=2.4, p=0.3 ; \alpha_{2 \mathrm{C}}-\mathrm{AR}: \mathrm{H}_{2,23}=15.37, p<$ 0.001 ) (Fig. $4 B$ and Fig. 4-1, available at https://doi.org/10.1523/ JNEUROSCI.1004-18.2018.f4-1). Local knock-down of $\alpha_{2 \mathrm{~A}}$, but not $\alpha_{2 \mathrm{C}}$, adrenoceptors suppressed the acute duloxetine action, pointing to a preferential involvement of $\alpha_{2 \mathrm{~A}}$ receptors $\left(F_{(1,28)}=\right.$ 20.1, $p<0.001$ ) (Fig. 4C and Fig. 4-1, available at https://doi.org/ 10.1523/JNEUROSCI.1004-18.2018.f4-1). In contrast, yohimbine, even when given chronically, had no influence on the delayed action of chronic duloxetine (Fig. 4D), whereas this action was blocked by chronic propranolol, an antagonist of $\beta$ adrenoceptors $\left(F_{(1,16)}=10.6, p<0.001\right)$ (Fig. $4 D$ and Fig. $4-1$, available at https:// doi.org/10.1523/JNEUROSCI.1004-18.2018.f4-1), and was lost in $\beta_{2}$ adrenoceptor-deficient $\left(\beta_{2}-\mathrm{AR}^{-1-}\right)$ mice $\left(F_{(8,120)}=3.6, p<\right.$ 0.001 ) (Fig. 4E, left, and Fig. 4-1, available at https://doi.org/10.1523/ JNEUROSCI.1004-18.2018.f4-1), whether male or female $\left(\beta_{2}\right.$ $\mathrm{AR}^{+/+}$male mice: $F_{(8,72)}=6.9, p<0.001 ; \beta_{2}-\mathrm{AR}^{+/+}$female mice: $F_{(8,72)}=2.6, p=0.003 ; \beta_{2}-\mathrm{AR}^{-1-}$ male mice: $F_{(8,48)}=3.6$, $p<0.001 ; \beta_{2}-\mathrm{AR}^{-1-}$ female mice: $F_{(8,48)}=2.1, p=0.027$ ) (Fig. $4 E$, right, and Fig. 4-1, available at https://doi.org/10.1523/ JNEUROSCI.1004-18.2018.f4-1). Interestingly, the acute action of duloxetine at high dose remained present in $\beta_{2}-\mathrm{AR}^{-1-}$ mice (Fig. $4 F$ ) and was not affected by propranolol (Fig. $4 A$ ). These data show that the acute transitory allodynia relief is mediated by an action of noradrenaline on $\alpha_{2 \mathrm{~A}}$ adrenoceptors, whereas the delayed action is mediated by $\beta_{2}$ adrenoceptors.

\section{Acute and prolonged duloxetine treatments recruit different opioid receptors}

The opioid system, via MOR, DOR, and KOR, plays a crucial role in the inhibitory control of pain (Gavériaux-Ruff and Kieffer, 2002; Dierich and Kieffer, 2004) and different studies have provided evidence for an involvement of the opioid system in the action of antidepressants on neuropathic pain (Kremer et al., 2016a). Acute duloxetine remained effective in $\mathrm{KOR}^{-l-}$ mice, but lost its action in $\mathrm{MOR}^{-1-}$ and in $\mathrm{DOR}^{-1-}$ mice $\left(\mathrm{MOR}^{-1-}: F_{(2,30)}=5.6, p=0.002\right.$; $\mathrm{DOR}^{-/-}: F_{(2,30)}=5.0, p=0.003$ ) (Fig. $5 \mathrm{~A}$ and Fig. 5-1, available at https://doi.org/10.1523/JNEUROSCI.1004-18.2018.f5-1). The involvement of opioid receptors was also confirmed pharmacologically by blocking acute duloxetine action with naloxone (Acute Dul Acute NLX: $F_{(1,15)}=19.5, p<0.001$ ) (Fig. $5 B$ and Fig. 5-1, available at https://doi.org/10.1523/JNEUROSCI.1004-18.2018.f5-1). Moreover, MOR and DOR implicated in acute duloxetine action are likely central because the peripheral antagonists naloxone methiodide and methylnaltrexone did not reverse the acute antiallodynic action of duloxetine (Acute Dul Acute NLX Meth: $F_{(1,21)}=19.0, p<0.001$; Acute Dul Acute MNTX: $F_{(1,15)}=19.3$, $p<0.001$ ) (Fig. 5B and Fig. 5-1, available at https://doi.org/ 10.1523/JNEUROSCI.1004-18.2018.f5-1). In contrast, after naloxone methiodide administration, mechanical allodynia reappeared in nerve injured mice chronically treated with duloxetine, thus pointing to the involvement of peripheral opioids (Chronic Dul Acute NLX Meth: $F_{(3,39)}=7.1, p<0.001$ ) (Fig. $5 C$ and Fig. 5-1, available at https://doi.org/10.1523/JNEUROSCI.1004-18.2018.f5$1)$. In this case, chronic treatment remained effective in $\mathrm{MOR}^{-/-}$ and $\mathrm{KOR}^{-1-}$ mice, but lost its action in $\mathrm{DOR}^{-1-}$ mice $\left(\mathrm{DOR}^{-1-}\right.$ : $F_{(8,120)}=3.8, p<0.001$ ) (Fig. $5 D$ and Fig. 5-1, available at https:// doi.org/10.1523/JNEUROSCI.1004-18.2018.f5-1). These data show that the long-term action of duloxetine depends on the presence of 
A
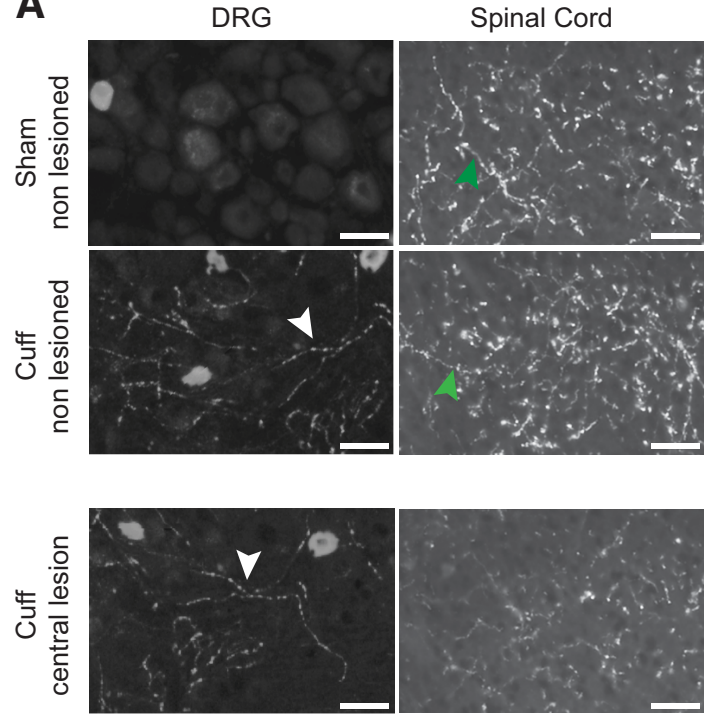

Central lesion of descending pathways (6-OHDA i.t.)

$-\mathrm{O}-$ Sham, Sacch (6/5)

- C Cuff, Sacch (7/7)

$\rightarrow$ Cuff, Dul (7/8)

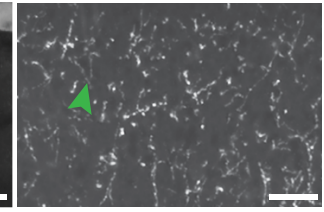

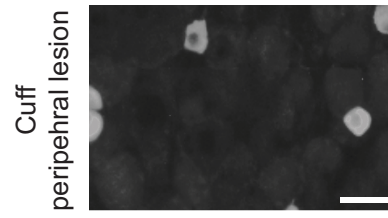

Peripheral lesion (Guanethidine i.p.)

$-\bigcirc$ Sham, Sacch (5/5)

- Cuff, Sacch (8/8)

$\rightarrow$ Cuff, Dul (8/8)
C

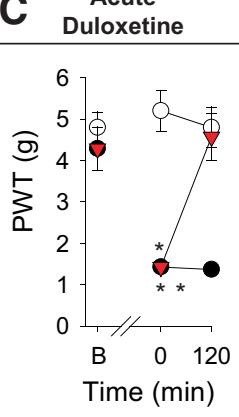

D Chronic
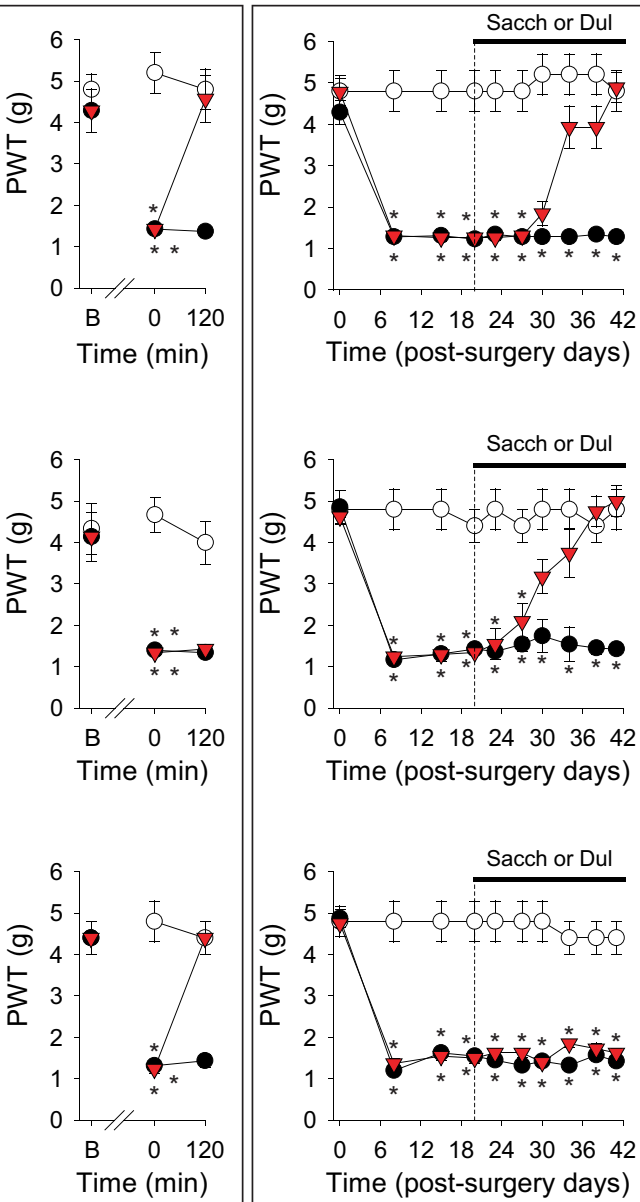

B Noradrenaline (pmol/mg protein) in lumbar spinal cord

\begin{tabular}{|l|c|c|}
\cline { 2 - 3 } \multicolumn{1}{c|}{} & Mean & SEM \\
\hline Sham, no lesion (7) & 24.94 & 1.03 \\
\hline Cuff, no lesion (7) & 24.89 & 0.78 \\
\hline Cuff, peripheral lesion (7) & 24.19 & 2.46 \\
\hline Cuff, central lesion (14) & $7.49 * * *$ & 0.30 \\
\hline
\end{tabular}

Dopamine (pmol/mg protein) in lumbar spinal cord

\begin{tabular}{|l|c|c|}
\cline { 2 - 3 } \multicolumn{1}{c|}{} & Mean & SEM \\
\hline Sham, no lesion (7) & 43.06 & 2.17 \\
\hline Cuff, no lesion (7) & 44.43 & 4.68 \\
\hline Cuff, peripheral lesion (7) & 49.05 & 10.19 \\
\hline Cuff, central lesion (14) & 42.38 & 2.12 \\
\hline
\end{tabular}

Figure 3. Noradrenergic substrate for the anti-allodynic action of duloxetine. Right PWTs were assessed using von Frey filaments. Lesions of noradrenergic pathways were done 2 weeks before the surgeries to induce neuropathic pain. Neuropathic pain was induced by inserting a cuff around the main branch of the sciatic nerve at least 2 weeks before the start of duloxetine treatment. $A$, TH immunostaining in the lumbar dorsal root ganglia (DRG; scale bars, $35 \mu \mathrm{m}$ ) and in the laminae II-III of the lumbar spinal cord (scale bars, $60 \mu \mathrm{m}$ ). Intrathecal 6-0HDA (central lesion, $20 \mu \mathrm{g}$, i.t.) allowed lesioning the noradrenergic descending pathways (green arrows: examples of fibers), whereas guanethidine (peripheral lesion, $30 \mathrm{mg} / \mathrm{kg}$, i.p.) allowed lesioning the sympathetic fiber sprouting in the DRG, which is consecutive to nerve injury (white arrows: examples of fibers). $\boldsymbol{B}$, Monoamine levels, measured by mass spectrometry, in the lumbar spinal cord confirmed that intrathecal 6-OHDA significantly reduced spinal noradrenaline levels. $n$ values are given in brackets. ${ }^{* *} p<0.01$ compared with other groups. $C$, Acute administration of duloxetine at high dose ( 30 $\mathrm{mg} / \mathrm{kg} \mathrm{p.o.)}$ ) induced a rapid anti-allodynic effect (top graph), which was suppressed by a central noradrenergic lesion (middle graph), but not by a peripheral lesion (bottom graph). $\boldsymbol{D}$, Chronic duloxetine treatment ( $200 \mu \mathrm{g} / \mathrm{ml}$ ) exerted a delayed anti-allodynic effect (top graph), which was suppressed by the peripheral noradrenergic lesion (bottom graph), but not by the central lesion (middle graph). Dul, Duloxetine; Sacch, saccharin. For all graphs, data are expressed as mean \pm SEM. " $B$ " corresponds to the PWT before surgery; "acute $n /$ chronic $n$ " are given in brackets, chronic treatment start and duration are indicated by the dotted and the thick lines in $\boldsymbol{D} .{ }^{*} p<0.05,{ }^{* * *} p<0.001$ compared with sham saccharin groups, one-way ANOVA was used for $\boldsymbol{B}$, ANOVA with repeated measures for $\boldsymbol{C}$ and $\boldsymbol{D}$. Detailed statistics are provided in Figure 3-1, available at https://doi.org/10.1523/JNEUROSCI.1004-18.2018.f3-1.

peripheral DOR, whereas acute effect at high dose requires central MOR and DOR.

Duloxetine plasma levels in patients are similar to those obtained in mice under prolonged treatment

Together, the previous findings highlight two independent mechanisms for duloxetine, both starting with the recruitment of noradrenaline: an acute transitory anti-allodynic action depend- ing on the central noradrenergic descending pathways mediated by $\alpha_{2 \mathrm{~A}}$ adrenoceptors and requiring the presence of central MOR and DOR; and a delayed anti-allodynic action peripherally mediated and involving $\beta_{2}$ adrenoceptors and DOR. Recent work also reported that this delayed action of duloxetine in the animal model persists for a few days after cessation of the chronic treatment (Salvat et al., 2018). These results raised the question of the mechanism(s) present in neuropathic pain patients chronically 

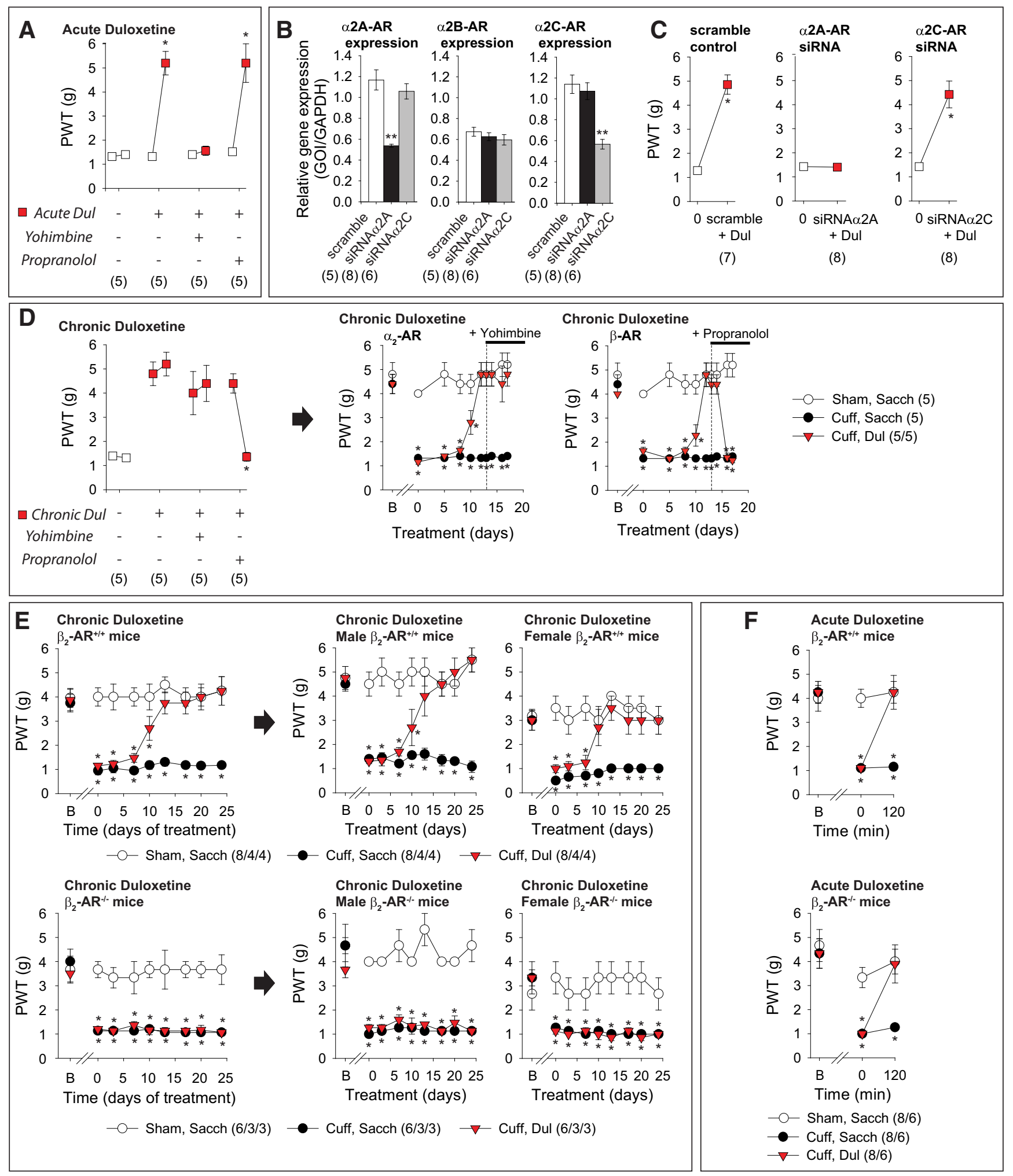

Figure 4. Role of the $\alpha$ and $\beta$ adrenoceptors in the anti-allodynic action of duloxetine. Right PWTs were assessed using von Frey filaments. Neuropathic pain was induced by inserting a cuff around the main branch of the sciatic nerve at least 2 weeks before the start of duloxetine treatment. $A$, In nerve-injured mice, chronic yohimbine $\left(\alpha_{2}\right.$ adrenoceptor antagonist, $20 \mu \mathrm{g} / \mathrm{ml}$ in drinking water for $5 \mathrm{~d}$ ), but not chronic propanolol ( $\beta$ adrenoceptor antagonist, $50 \mu \mathrm{g} / \mathrm{ml}$ in drinking water for $5 \mathrm{~d}$ ), prevented the acute action of a high dose of duloxetine ( $30 \mathrm{mg} / \mathrm{kg}$ p.0.; $n$ are given in brackets, ${ }^{*} p<0.05$ compared with time before acute administration). $\boldsymbol{B}$, Selective decrease in mRNA expression was observed in nerve-injured mice $72 \mathrm{~h}$ following siRNA intrathecal delivery (1 nmol; $n=6-8$ mice/group, ${ }^{* *} p<0.01$ compared with scramble Groups). GOl, gene of interest. $C, \alpha_{2 A}$, but not $\alpha_{2,}$, adrenoceptor knock-down by siRNA suppressed the acute effect of duloxetine ( $n$ values are given in brackets, ${ }^{*} p<0.05$ compared with time before acute administration). $\boldsymbol{D}$, In nerve-injured mice, chronic propranolol but not chronic yohimbine suppressed the anti-allodynic action of chronic duloxetine ( $200 \mu \mathrm{g} / \mathrm{ml}, n$ values are given in brackets, ${ }^{*} p<0.05$ compared with time before antagonist administration or to sham saccharin groups). The two graphs on the right display the detailed time course of the experiment summarized on the left. In the time course graphs, duloxetine was provided from the first day of treatment and the start and duration of the antagonist cotreatment are indicated by the dotted and the thick lines. $E, \ln \beta 2-\mathrm{AR}^{+/+}$mice, chronic oral duloxetine $(200 \mu \mathrm{g} / \mathrm{ml})$ suppressed the ipsilateral allodynia but remained ineffective in $\beta 2-A R^{-1-}$ mice. The left graphs display data from all $\beta 2-\mathrm{AR}^{+/+}$and $\beta 2-\mathrm{AR}^{-1-}$ mice, whereas the right graphs present results separately in males and females. (Figure legend continues.) 

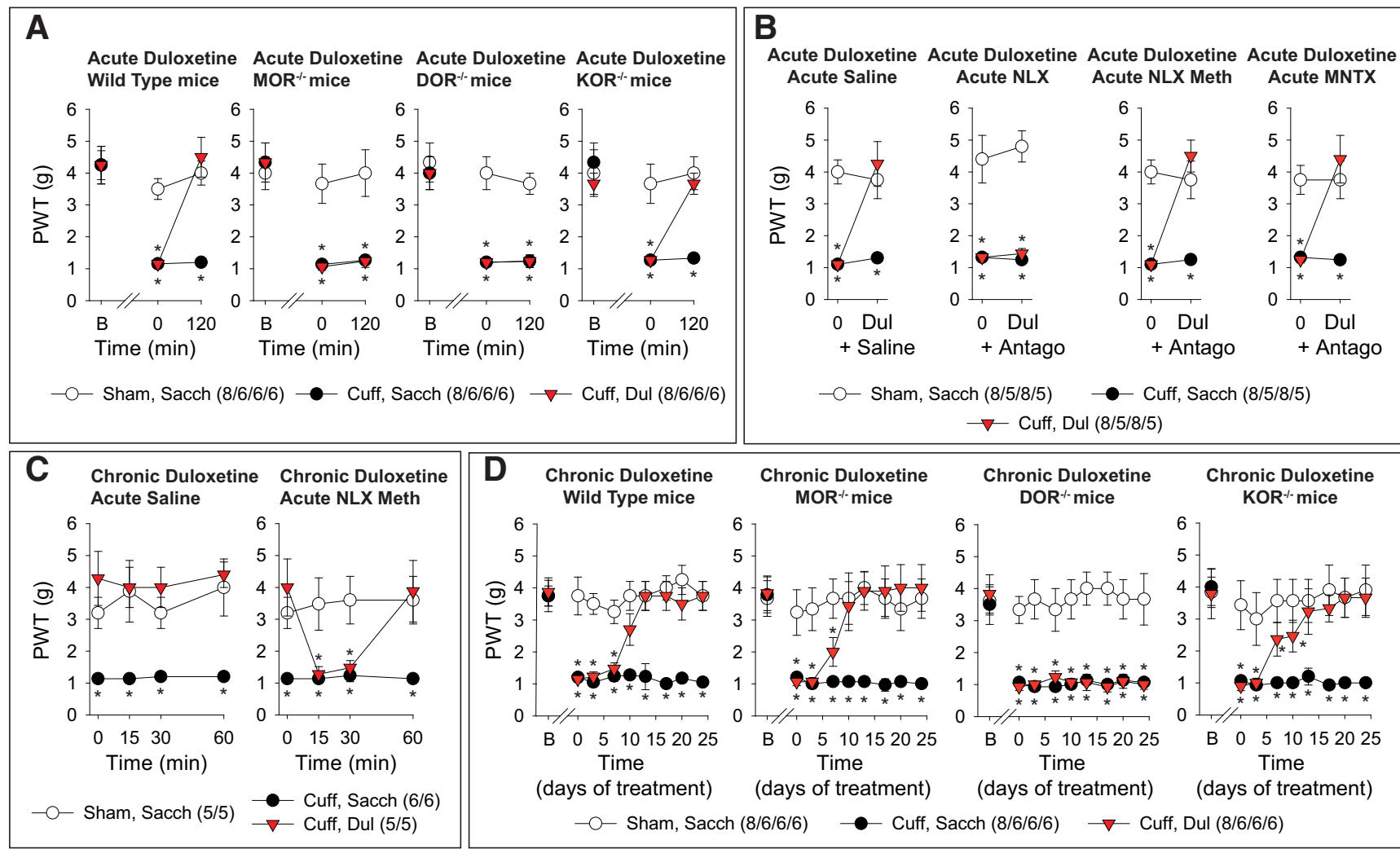

(days of treatment)

(days of treatment)

(days of treatment)

(days of treatment)

- - Sham, Sacch $(8 / 6 / 6 / 6)$

Figure 5. Role of opioid receptors in the anti-allodynic effect of duloxetine. PWTs were assessed using von Frey filaments. Neuropathic pain was induced by inserting a cuffaround the main branch of the sciatic nerve at least 2 weeks before the start of duloxetine treatment. $A$, Acute administration of a high dose of duloxetine ( $30 \mathrm{mg} / \mathrm{kg}, \mathrm{p} .0$.) relieved mechanical allodynia in WT and in KOR ${ }^{-} /-$ mice, but not in DOR ${ }^{-1-}$ and in MOR ${ }^{-1-}$ mice. $B$, An acute injection of the nonselective opioid receptor antagonist naloxone (NLX, 1 mg/kg, s.c.), but not of the peripheral antagonists naloxone methiodide (NLX Meth, $5 \mathrm{mg} / \mathrm{kg}$, S.C.) and methylnaltrexone (MNTX, $10 \mathrm{mg} / \mathrm{kg}$, s.C.), suppressed the anti-allodynic action of acute duloxetine. C, An acute injection of the peripheral opioid receptor antagonist naloxone methiodide induced a relapse of allodynia in mice chronically treated with duloxetine. D, Chronic oral duloxetine (200 $\mu \mathrm{g} / \mathrm{ml}$ ) suppressed the ipsilateral allodynia in WT, $\mathrm{MOR}^{-1-}$, and KOR ${ }^{-1-}$ mice, but it remained ineffective in DOR ${ }^{-1-}$ mice. Dul, Duloxetine; Sacch, saccharin. Data are expressed as mean \pm SEM. "B" corresponds to the mechanical threshold sensitivity of right paw before surgery; "WT $n / \mathrm{MOR}^{-1-} n / \mathrm{DOR}{ }^{-1-} n / \mathrm{KOR}^{-1-} n^{\prime \prime}$ or "Saline $n / \mathrm{NLX} n / \mathrm{NLX}$ Meth $n / \mathrm{MNTX} n^{\prime \prime}$ are given in brackets. * $p<0.05$ compared with sham saccharin groups, ANOVA with repeated measures was used for $\boldsymbol{A}-\boldsymbol{D}$. Detailed statistics are provided in Figure 5-1, available at https://doi.org/10.1523/JNEUROSCl.1004-18.2018.f5-1.

treated with duloxetine. We thus used mass spectrometry to compare drug plasma levels in duloxetine-treated mice and patients. In mice with nerve injury, plasmatic levels of acutely delivered duloxetine were directly correlated over time to the PWT $(r=0.90, p<0.001$; Fig. $6 A)$. A full relief from neuropathic allodynia was observed $2 \mathrm{~h}$ after duloxetine administration $\left(F_{(1,55)}=39.6, p<0.001\right)$ (Fig. $6 A$ ), corresponding to plasmatic concentrations of $5700 \pm 600 \mathrm{~nm}$ (Fig. 6A). However, plasma levels of duloxetine in nerve injured mice receiving prolonged treatment and displaying full relief from allodynia were in the range of a few hundred nanomolar $(376 \pm 65 \mathrm{~nm}$ on the morning, $453 \pm 46 \mathrm{nM}$ on the evening), which is $\sim 12$ times lower than observed for the acute procedure (Fig. $6 B$ ). In patients from various neuropathic etiologies and partially relieved from neuropathic pain by chronic duloxetine treatment (60 mg once a day) (Table 1), the plasmatic peak concentration was $297 \pm 61 \mathrm{nM}$,

(Figure legend continued.) $\quad F$, Acutely, a high dose of duloxetine $(30 \mathrm{mg} / \mathrm{kg}$, p.o.) suppressed mechanical allodyna in both $\beta 2-\mathrm{AR}^{+/+}$and $\beta 2-\mathrm{AR}^{-/-}$mice. Dul, Duloxetine; Sacch, saccharin. Data are expressed as mean \pm SEM. " $B$ " corresponds to the mechanical threshold sensitivity of right paw before surgery. AR, Adrenoceptor; " $\beta 2-\mathrm{AR}^{+/+} n / \beta 2-\mathrm{AR}^{-/-} n^{\text {" }}$ are given in brackets. ${ }^{*} p<0.05$ compared with sham saccharin groups, one-way ANOVA was used for $\boldsymbol{A}$ and $\boldsymbol{C}$ and $\boldsymbol{D}$, Kruskal-Wallis test for $\boldsymbol{B}$ and ANOVA with repeated measures for $\boldsymbol{D}-\boldsymbol{F}$. Detailed statistics are provided in Figure 4-1, available at https://doi.org/ 10.1523/JNEUROSCI.1004-18.2018.f4-1. whereas the residual plasmatic levels before morning duloxetine intake was $119 \pm 23 \mathrm{~nm}$ (Fig. 6B). These plasma concentrations in patients were comparable to those measured in animals under prolonged treatment, which highlights the potential relevance of the peripheral mechanism of duloxetine action.

\section{Peripheral nerve injury leads to a remodeling of dorsal root ganglia, whereas prolonged duloxetine treatment has an anti-neuroimmune effect}

To go further in understanding this peripheral component of duloxetine action, we conducted a transcriptomic analysis using RNA sequencing. Following 5 weeks of nerve injury, we still observed significant changes in the expression of 193 genes in the dorsal root ganglia, with two-thirds of them being upregulated (Fig. 7A). The DAVID functional analysis showed that these molecular changes correspond to a remodeling of the dorsal root ganglia, with a particular impact on the extracellular matrix, integrin signaling, and cell differentiation (Fig. $7 B$ ). Conversely, half as many genes were significantly affected by chronic duloxetine treatment, with two-thirds of them downregulated (Fig. $7 C)$. The functional analysis showed that duloxetine primarily affected neurogenic inflammation, as reflected by the presence of genes regulating inflammation via immune response or cytokine response (Fig. 7D). The impact of chronic duloxetine on neurogenic inflammation is further supported by GSEA. Indeed, significant enrichment of TNF- $\alpha$ signaling via NF- $\kappa$ B was observed 


\section{A}

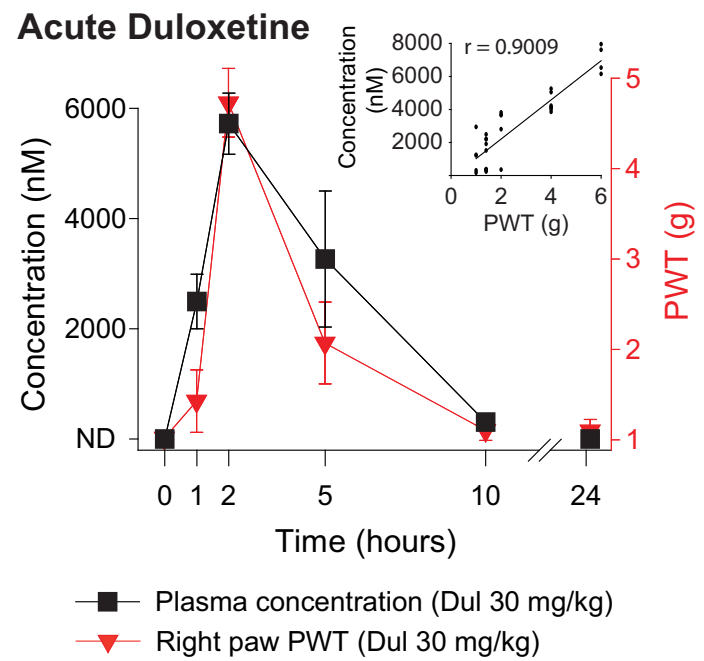

B Acute Duloxetine

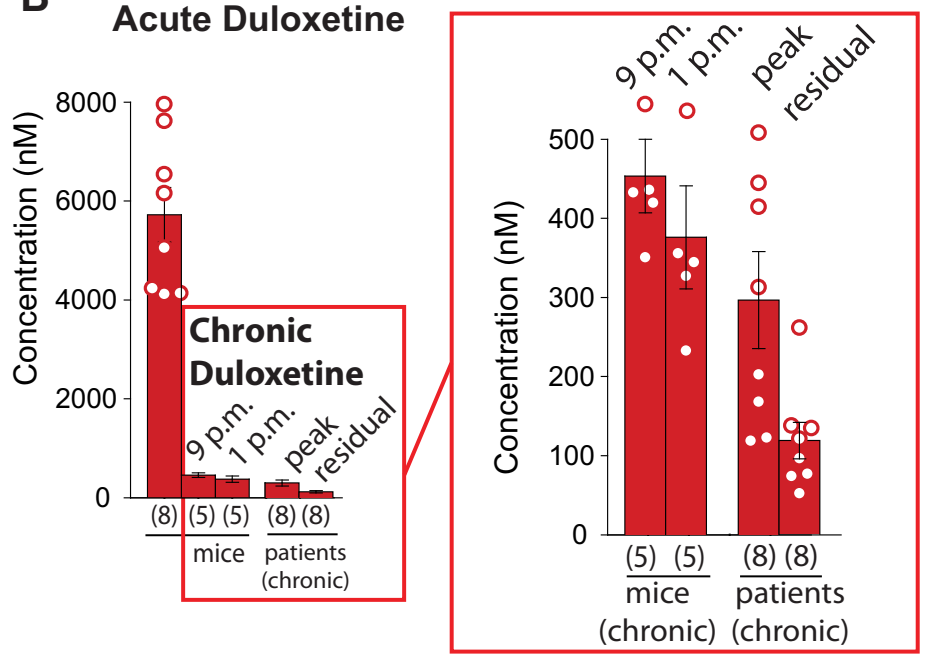

Figure 6. Duloxetine plasma concentrations in mice and in human patients. In mice, right PWTs were assessed using von Frey filaments and neuropathic pain was induced by inserting a cuff around the main branch of the sciatic nerve at least 2 weeks before the start of duloxetine treatment. Dosage in the clinical setting was done on neuropathic pain patients chronically treated with duloxetine (Cymbalta, $60 \mathrm{mg}$ daily in one intake) and reporting relief of at least $30 \%$ of their neuropathic pain since the initiation of the treatment. Duloxetine plasma concentrations were determined using mass spectrometry. $\boldsymbol{A}$, Comparison of mean plasma concentration-time profile and behavioral data for acute duloxetine oral administration in mice ( $30 \mathrm{mg} / \mathrm{kg}, \mathrm{p} .0 . ; n=7$ or 8 per each time point). The insert shows the correlation between duloxetine plasma levels and PWT for animals with detectable duloxetine plasma levels (time points from 1 to $24 \mathrm{~h}, n=38$ total). $\boldsymbol{B}$, Mean plasma concentration of duloxetine $2 \mathrm{~h}$ after acute oral administration ( $30 \mathrm{mg} / \mathrm{kg}, \mathrm{p} .0$.) and after a chronic oral treatment ( $200 \mu \mathrm{g} / \mathrm{ml}, 3 \mathrm{weeks}$ ) in mice, as well as $6 \mathrm{~h}$ (peak) after the daily intake of the chronic treatment ( $60 \mathrm{mg}$ per day) or in the morning (residual) just before duloxetine intake, in patients with neuropathic pain. Data are expressed as mean \pm SEM. $n$ values are given in brackets. ND, Nondetectable.

Table 1. Characteristics of patients included in the duloxetine plasma dosage study

\begin{tabular}{|c|c|c|c|c|c|c|c|c|}
\hline Patient ID & & Gender & Age (y) & Weight (kg) & Etiology of NP & & Location of NP & Concomitant treatments \\
\hline 01 & & $\mathrm{~F}$ & 68 & 80 & Traumatic & & $\mathrm{C} 7$ & \\
\hline 02 & & $\mathrm{~F}$ & 52 & 75 & Traumatic & & $\mathrm{L} 3$ & \\
\hline 03 & & $\mathrm{~F}$ & 51 & 55 & Traumatic & & $\mathrm{C} 7$ & \\
\hline 04 & & $\mathrm{~F}$ & 43 & 55 & Traumatic & & $\mathrm{C} 7$ & \\
\hline 05 & & M & 66 & 76 & Diabetic & & Lower limbs & Baclofen $10 \mathrm{mg}$ \\
\hline 06 & & $\mathrm{~F}$ & 43 & 60 & Stroke & & Left hemibody & \\
\hline 07 & & M & 30 & 70 & Traumatic & & S1 & \\
\hline \multirow[t]{2}{*}{08} & & $\mathrm{~F}$ & 46 & 65 & Traumatic & & $\mathrm{C} 6$ & \\
\hline & $\begin{array}{l}\text { Treatment } \\
\text { duration }\end{array}$ & & $\begin{array}{l}\text { NRS before duloxetine } \\
\text { treatment }\end{array}$ & $\begin{array}{l}\text { NRS after duloxetine } \\
\text { treatment V0 }\end{array}$ & $\begin{array}{l}\text { NRS after duloxetine } \\
\text { treatment V1 }\end{array}$ & PGIC & $\begin{array}{l}\text { Residual plasma level } \\
\text { V0 (nM) }\end{array}$ & $\begin{array}{l}\text { Peak plasma level } \\
\text { V1 (nM) }\end{array}$ \\
\hline 01 & $3 \mathrm{mo}$ & & 7 & 4 & 4 & 2 & 96.49 & 167.96 \\
\hline 02 & $1 y$ & & 6 & 2 & 1 & 1 & 76.57 & 122.4 \\
\hline 03 & $5 \mathrm{mo}$ & & 8 & 4 & 4 & 2 & 261.28 & 591.06 \\
\hline 04 & $6 \mathrm{mo}$ & & 8 & 4 & 4 & 2 & 73.72 & 414.3 \\
\hline 05 & $1 y$ & & 8 & 1 & 1 & 1 & 120.86 & 444.37 \\
\hline 06 & $2 \mathrm{mo}$ & & 4 & 2 & 2 & 3 & 137.54 & 202.28 \\
\hline 07 & $6 \mathrm{mo}$ & & 8 & 4 & 4 & 2 & 52.11 & 118.36 \\
\hline 08 & $1 \mathrm{mo}$ & & 9 & 3 & 3 & 1 & 134.51 & 312.75 \\
\hline
\end{tabular}

NP, Neuropathic pain; NRS, numeric rating scale; PGIC, patients' global impression of change; V0, visit before the morning drug intake; V1, visit $6 \mathrm{~h}$ after the morning drug intake.

following nerve injury (ES $=0.42, p<0.00001$ ) (Fig. $7 E$ ), whereas chronic duloxetine downregulated gene expression associated to this pathway (ES $=-0.34, p=0.002$ ) (Fig. $7 E$ ). Although few of the nerve-injury-related individual genes were significantly altered by the treatment, chronic duloxetine mostly blunted the overexpression and underexpression of half of all these genes. Therefore, only $41.9 \%$ of the nerve injured-related genes still displayed significant changes following chronic duloxetine treatment (Fig. 7F).

\section{Prolonged duloxetine treatment displays an indirect anti-TNF- $\alpha$ action}

Nerve injury has been shown to overexpress the membrane bound $(26 \mathrm{kDa})$ TNF- $\alpha$ (mTNF- $\alpha)$ in the lumbar dorsal root ganglia, which can be corrected by nortriptyline (Bohren et al., 2013). Here, we confirmed such overexpression of mTNF- $\alpha$ in male mice and showed that it can be dose-dependently corrected by chronic duloxetine treatment $\left(H_{(3,35)}=15.8, p<0.001\right)$ (Fig. $8 A$ and Fig. 8-1, available at https://doi.org/10.1523/JNEUROSCI.100418.2018.f8-1). We also found similar results in female mice $\left(H_{(2,21)}\right.$ $=7.6, p=0.022$ ) (Fig. $8 B$ and Fig. $8-1$, available at https://doi.org/ 10.1523/JNEUROSCI.1004-18.2018.f8-1). Interestingly, $2 \mathrm{~h}$ after acute administration of duloxetine, at the peak of the acute antiallodynic action, this anti-TNF- $\alpha$ effect was not present at protein level $\left(H_{(2,21)}=6.7, p=0.034\right)$ (Fig. $8 \mathrm{C}$ and Fig. 8-1, available at https://doi.org/10.1523/JNEUROSCI.1004-18.2018.f8-1), which further highlights that different mechanisms underlie acute versus chronic action of the drug. 
A

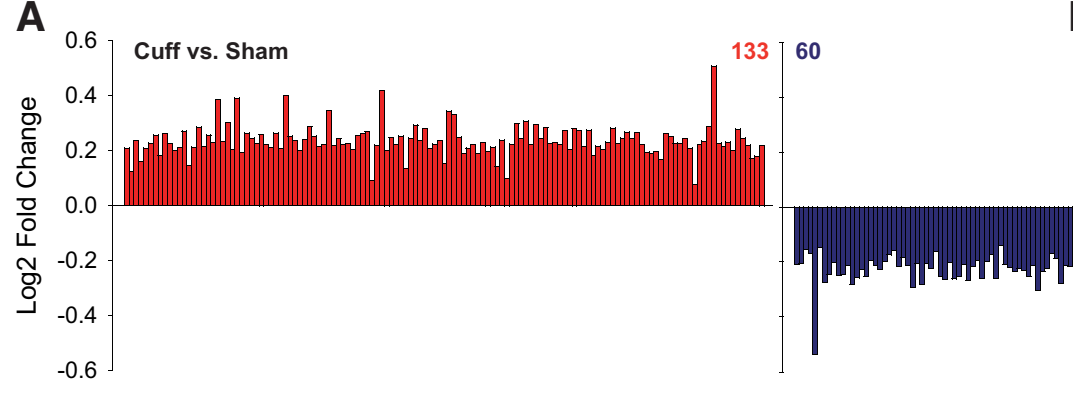

C

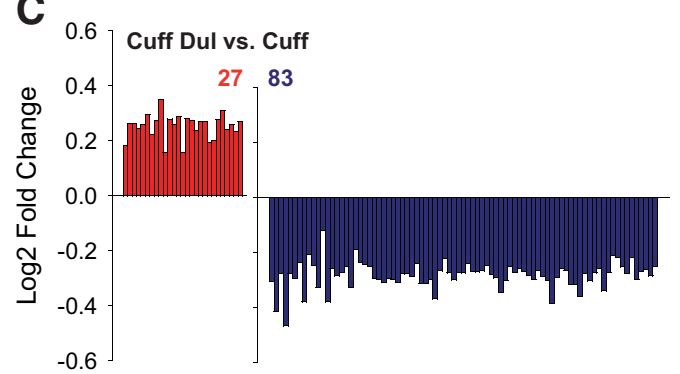

B

Cuff vs. Sham: Functional enrichment

\begin{tabular}{ccc}
\hline Function Annotation & p-value & Example genes \\
\hline $\begin{array}{c}\text { extracellular structure } \\
\text { organization }\end{array}$ & $4.05 \mathrm{E}-13$ & $\begin{array}{c}\text { adam8, mfap4, mmp16, } \\
\text { col3a1, col6a1 }\end{array}$ \\
\hline cell-cell signaling & $2.21 \mathrm{E}-07$ & $\begin{array}{c}\text { gjd2, chrnb3, ucn, pkp2, } \\
\text { fgf3 }\end{array}$ \\
\hline regulation of cell differentiation & $1.81 \mathrm{E}-06$ & $\begin{array}{c}\text { cdkn2a, erbb2, adam8, } \\
\text { draxin, pkp2 }\end{array}$ \\
\hline glial cell differentiation & $3.40 \mathrm{E}-06$ & $\begin{array}{c}\text { erbb2, erbb3, pou3f1, } \\
\text { aspa, sox2 }\end{array}$ \\
\hline regulation of cell adhesion & $4.11 \mathrm{E}-06$ & $\begin{array}{c}\text { cyp1b1, il12rb1, smoc2, } \\
\text { itgb3, rnd1 }\end{array}$ \\
\hline
\end{tabular}

D

\begin{tabular}{|c|c|c|}
\hline Function Annotation & $p$-value & Example genes \\
\hline innate immune response & 3.34E-07 & $\begin{array}{l}\text { gbp6, hla-a, gbp7, Icn2, } \\
\text { ifi16 }\end{array}$ \\
\hline $\begin{array}{l}\text { cellular response to interferon- } \\
\text { gamma }\end{array}$ & 4.50E-06 & $\begin{array}{l}\text { gbp6, hla-a, gbp7, trim5, } \\
\text { gbp4 }\end{array}$ \\
\hline immune response & $1.73 \mathrm{E}-05$ & $\begin{array}{l}\text { klhl6, gbp6, il31ra, hla-a, } \\
\text { gbp7 }\end{array}$ \\
\hline response to cytokine & $5.66 \mathrm{E}-05$ & $\begin{array}{l}\text { il31ra, ifi16, mid1, xaf1, } \\
\text { ip6k2 }\end{array}$ \\
\hline $\begin{array}{l}\text { cellular response to cytokine } \\
\text { stimulus }\end{array}$ & $6.29 \mathrm{E}-05$ & $\begin{array}{c}\text { gbp6, gbp7, trim5, uba7, } \\
\text { nlrc5 }\end{array}$ \\
\hline
\end{tabular}

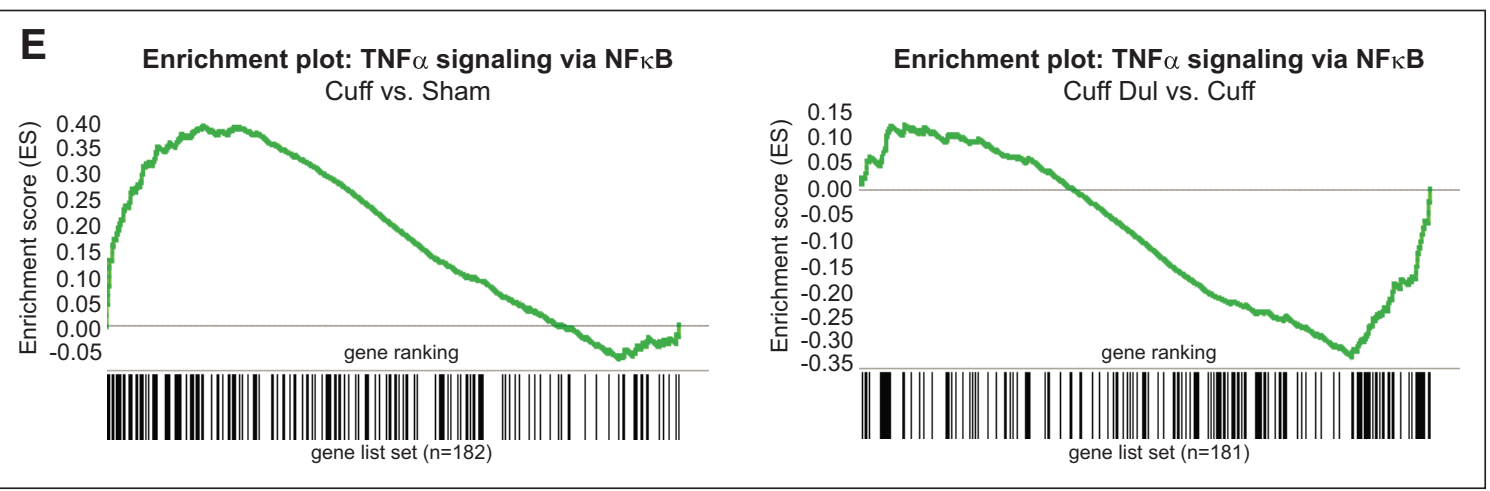

$\mathbf{F}$

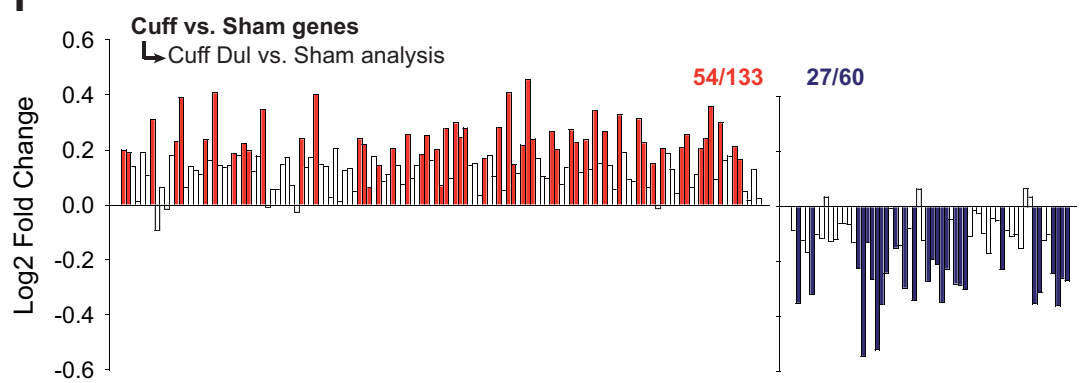

Figure 7. Impact of nerve injury and chronic duloxetine treatment on dorsal root ganglia transcriptome. Neuropathic pain was induced by inserting a cuff around the main branch of the sciatic nerve. Chronic oral duloxetine treatment started at least 2 weeks postsurgery and lasted for 3 weeks. The presence and relief of mechanical allodynia were tested using von Frey filaments. L4, L5, and L6 dorsal root ganglia were collected for molecular analysis. $A$, Representation of genes significantly upregulated (red) and downregulated (blue) in dorsal root ganglia following sciatic nerve injury. The numbers above the graphs indicate the number of genes that showed significant changes in expression. $\boldsymbol{B}$, Based on the analysis using the DAVID Bioinformatics Resources (which consider sets of genes known to be functionally related), the table shows the top functional changes concerning gene expression in the dorsal root ganglia following nerve injury. The function annotations are the one identified under DAVID analysis; only the five highest $p$-value functional changes are displayed, examples of genes with significant differential expression and belonging to the functionally related gene list are provided. $C$, Representation of genes significantly upregulated (red) and downregulated (blue) in dorsal root ganglia following long-term duloxetine treatment. The numbers above the graphs indicate the number of genes that showed significant changes in expression. $\boldsymbol{D}$, Based on DAVID analysis, the table shows the top functional changes concerning gene expression in the dorsal root ganglia following long-term duloxetine treatment in mice with neuropathic pain. $\boldsymbol{E}$, At the gene expression level, peripheral nerve injury induced an upregulation of the TNF- $\alpha$ signaling via NF- $\kappa$ B, whereas chronic duloxetine downregulated this signalization, as shown by GSEA. In these graphs, the $x$-axis represents the distribution of genes, from the most strongly upregulated to the most strongly downregulated ("gene ranking"). The distribution of the black lines below represents the genes (each line) in the list of genes belonging to the TNF- $\alpha$ signaling via NF- $\kappa$ B according to GSEA software. Because one of the genes was not expressed in the duloxetine-treated group, the gene list set is of 181 genes instead of 182 for this analysis. $\boldsymbol{F}$, The 193 genes showing significant changes after sciatic nerve injury (cf. $\boldsymbol{A}$ ) were analyzed in a comparison between duloxetine-treated Cuff mice and sham mice. In this context, only $41.9 \%$ of nerve-injury-related genes still displayed significant changes (upregulation in red, downregulation in blue) following chronic duloxetine treatment. This indicates that chronic duloxetine treatment blunted the overexpression or downregulation of $58 \%$ of the genes altered by nerve injury (white bars). The numbers above the graphs indicate the number of genes that still showed significant changes in expression after duloxetine treatment among genes with expression that was altered in the neuropathic pain condition. 
A
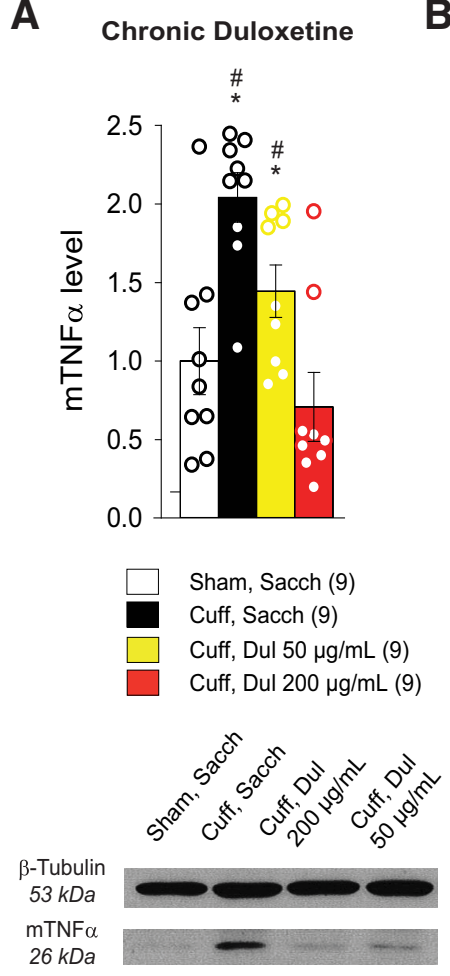

E

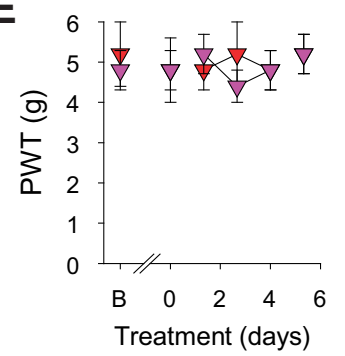

$-\nabla$ Sham, Adalimumab (5)
$-\nabla$ Sham, Certolizumab (5)
B

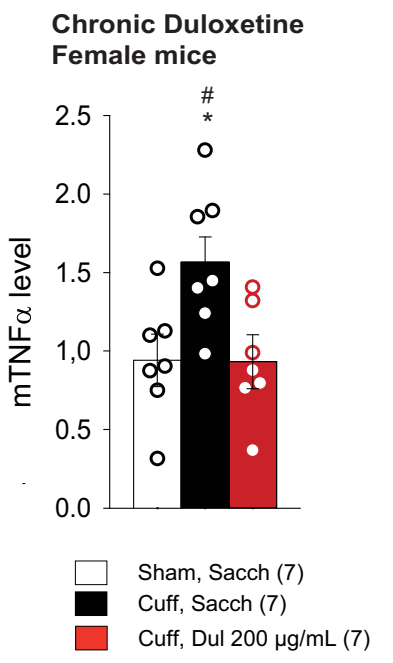

C Acute Duloxetine

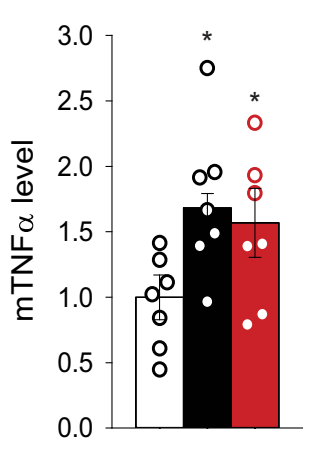

\begin{tabular}{|l}
$\square \quad$ Sham, Sacch (7) \\
Cuff, Sacch (7) \\
Cuff, Dul $30 \mathrm{mg} / \mathrm{kg} \mathrm{(7)}$
\end{tabular}

D

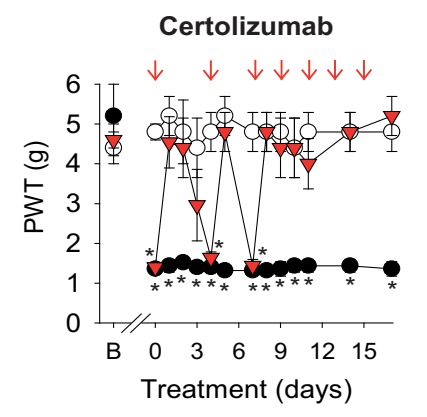

- - Sham, Saline (5)

- Cuff, Saline (5)

$\checkmark-$ Cuff, Anti-TNF $\alpha$ treatments (5/5)
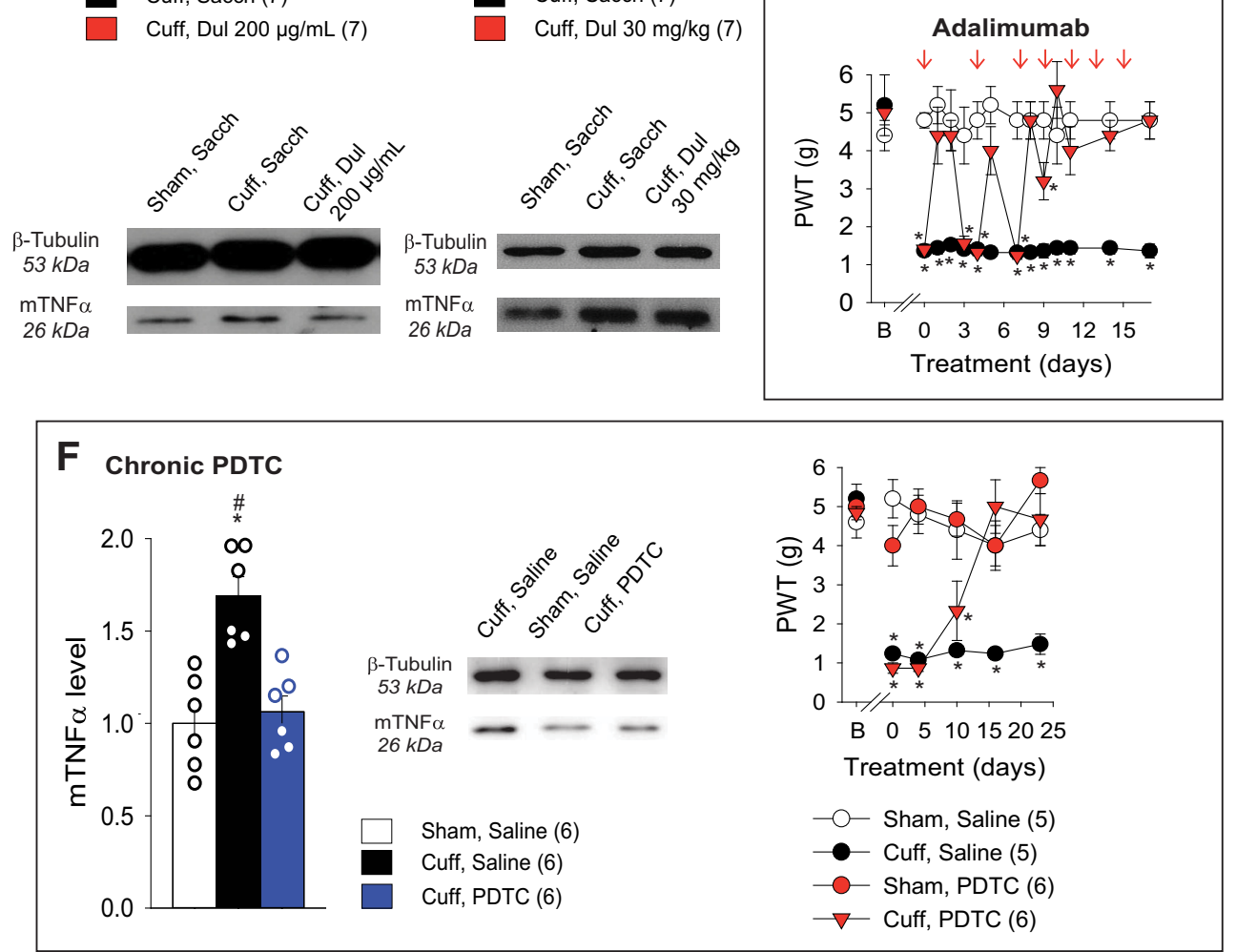

Figure 8. Effect of duloxetine impact on TNF- $\alpha$. Neuropathic pain was induced by inserting a cuff around the main branch of the sciatic nerve. Treatments started at least 2 weeks postsurgery. The presence and relief of mechanical allodynia were tested using von Frey filaments. $\mathrm{L} 4, \mathrm{~L} 5$, and $\mathrm{L} 6$ dorsal root ganglia were collected for molecular analysis. $A$, Western blot analysis of dorsal root ganglia showed increased mTNF- $\alpha$ levels in male mice after nerve injury and an anti-TNF- $\alpha$ action after chronic duloxetine treatment (200 $\mu \mathrm{g} / \mathrm{ml}, 3$ weeks). $\boldsymbol{B}$, Western blot analysis of dorsal root ganglia showed increased mTNF- $\alpha$ levels in female mice after nerve injury and an anti-TNF- $\alpha$ action of the chronic duloxetine treatment (200 $\mu \mathrm{g} / \mathrm{ml}, 3$ weeks). $\boldsymbol{C}$, Acute duloxetine treatment ( 30 $\mathrm{mg} / \mathrm{kg}$, p.o.) did not affect the increased mTNF- $\alpha$. D. The anti-TNF- $\alpha$ biotherapies certolizumab $(6 \mathrm{mg} / \mathrm{kg})$ and adalimumab $(1 \mathrm{mg} / \mathrm{kg})$ relieved neuropathic allodynia. The arrows represent the injection times. $\boldsymbol{E}$, Certolizumab $(6 \mathrm{mg} / \mathrm{kg}$, injected once) and adalimumab (1 mg/kg, injected once) did not modify the mechanical threshold of control animals ( $n$ values are given in brackets). $F$, Chronic PDTC treatment ( $20 \mathrm{mg} / \mathrm{kg}$, i.p., two injections per day) suppressed the neuropathy-induced mTNF- $\alpha$ overexpression in the dorsal root ganglia and exerted an anti-allodynic action. Dul, Duloxetine; Sacch, saccharin. Data are expressed as mean \pm SEM. $n$ values are given in brackets. "B" (for baseline) corresponds to the mechanical threshold sensitivity before surgery. ${ }^{*} p<0.05$ compared with sham saccharin/saline groups; \#p $<0.05$ compared with cuff treatments groups. Kruskal-Wallis test was used for Western blot data in $\boldsymbol{A}-\boldsymbol{C}$ and $\boldsymbol{F}$, ANOVA with repeated measures was used for behavioral data in $\boldsymbol{D}-\boldsymbol{F}$. Detailed statistics are provided in Figure 8-1, available at https://doi.org/10.1523/JNEUROSCI.1004-18.2018.f8-1.

We then explored whether the anti-TNF- $\alpha$ action or an inhibition of the NF- $\kappa$ B pathway would be relevant to neuropathic pain relief. We first tested the clinically used antiTNF- $\alpha$ biotherapies certolizumab and adalimumab on neuropathic allodynia. Both drugs suppressed this symptom at each administration (certolizumab: $F_{(13,156)}=4.7, p<$ 0.001 ; adalimumab: $\left.F_{(13,156)}=5.3, p<0.001\right)$ (Fig. $8 D$ and Fig. 8-1, available at https://doi.org/10.1523/JNEURO-
SCI.1004-18.2018.f8-1) in nerve-injured animals, but had no analgesic action in control animals (Fig. $8 E$ ). Because TNF- $\alpha$ recruitment was accompanied by a recruitment of the NF- $\kappa$ B pathway, we also tested its implication by treating the mice with the NF- $\kappa$ B pathway inhibitor PDTC, which suppressed both the nerve-injury-induced increase in mTNF- $\alpha\left(H_{(2,18)}=\right.$ $11.5, p=0.003$ ) (Fig. $8 F$ and Fig. 8-1, available at https:// doi.org/10.1523/JNEUROSCI.1004-18.2018.f8-1) and the 
A

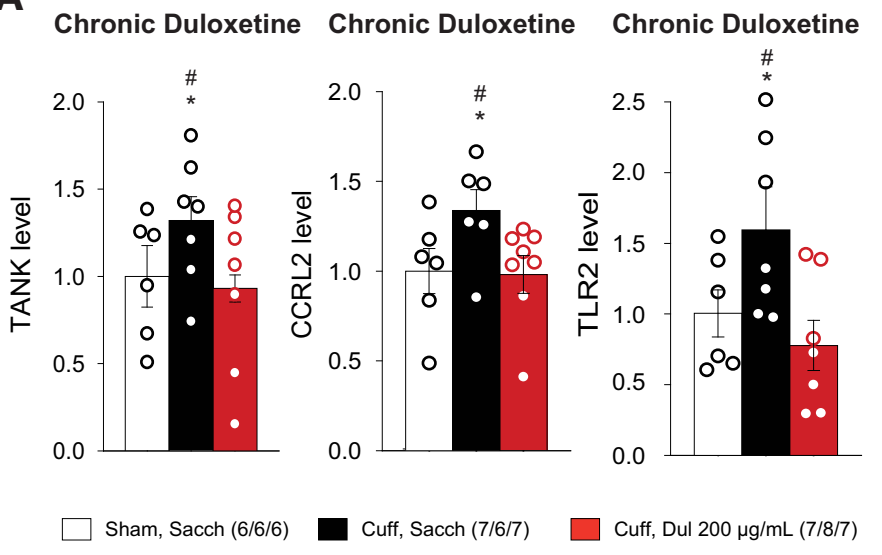

B

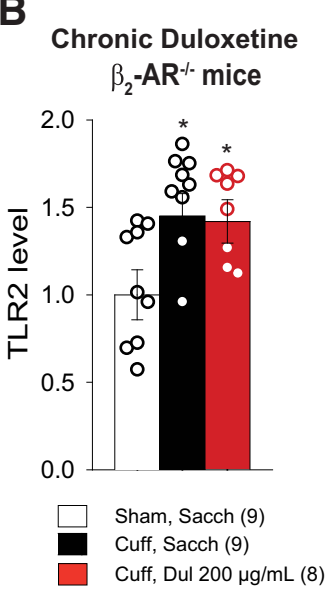

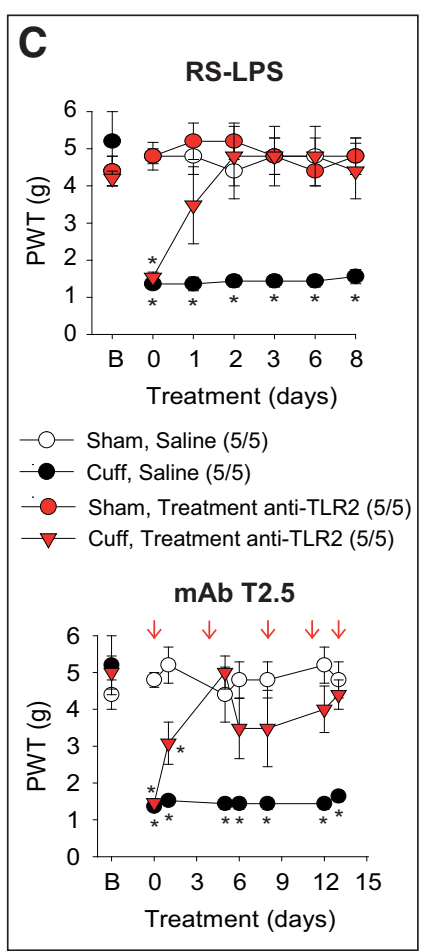

Figure 9. Effect of duloxetine on members of the TNF- $\alpha$ signaling via NF- $\kappa$ B. Neuropathic pain was induced by inserting a cuff around the main branch of the sciatic nerve. Chronic oral duloxetine treatment started at least 2 weeks postsurgery and lasted for 3 weeks. The presence and relief of mechanical allodynia were tested using von Frey filaments. $L 4$, L5, and $L 6$ dorsal root ganglia were collected for molecular analysis. Treatments acting on TLR started at least 2 weeks postsurgery. $\boldsymbol{A}$, Western blot analysis of TANK, CCRL2, and TLR2 in the dorsal root ganglia. Chronic duloxetine treatment suppressed the overexpression of these proteins observed in nerve-injured animals. $\boldsymbol{B}$, Duloxetine treatment did not suppress the overexpression of TLR2 in $\beta 2$-AR ${ }^{-1-}$ mice. $\boldsymbol{C}$, The TLR2/TLR4 antagonist RS-LPS ( $0.1 \mathrm{mg} / \mathrm{kg}$, 2 injections per day) or the anti-TLR2 mAb T2.5 ( $2 \mu$ g per mouse injected every $4 \mathrm{~d}$; arrows represent the injections) relieved neuropathic allodynia. Data are expressed as mean \pm SEM. $n$ values are given in brackets. "B" (for baseline) corresponds to the mechanical threshold sensitivity before surgery. ${ }^{*} p<0.05$ compared with sham saccharin/saline groups; \#p $<0.05$ compared with cuff treatments groups. Kruskal-Wallis test was used for $\boldsymbol{A}$ and $\boldsymbol{B}$; ANOVA with repeated measures was used for $\boldsymbol{C}$. Detailed statistics are provided in Figure 9-1, available at https://doi.org/10.1523/JNEUROSCI.1004-18.2018.f9-1.

mechanical hypersensitivity $\left(F_{(5,90)}=7.7, p<0.001\right)$ (Fig. $8 F$ and Fig. 8-1, available at https://doi.org/10.1523/JNEUROSCI. 1004-18.2018.f8-1).

\section{Prolonged duloxetine treatment affects different members of TNF- $\alpha-N F-\kappa B$ pathway}

In addition to this direct assessment of treatment impact on TNF- $\alpha$, we further explored some members of the TNF- $\alpha-$ NF- $\kappa$ B pathway, the gene expression of which was globally enhanced following nerve injury and downregulated by chronic duloxetine treatment: TANK, CCRL2, and TLR2. All three proteins were overexpressed in the lumbar dorsal root ganglia of nerve injured mice, which was reversed by chronic duloxetine treatment (TANK: $H_{(2,20)}=3.2, p=0.02$; CCLR2: $H_{(2,20)}=5.7, p=0.04$; TLR2: $H_{(2,20)}=5.1, p=0.046$ ) (Fig. $9 A$ and Fig. 9-1, available at https://doi.org/10.1523/JNEUROSCI.1004-18.2018.f9-1) and we showed that the action of duloxetine on TLR2 expression was dependent upon $\beta_{2}$ adrenoceptors $\left(\beta_{2}-\mathrm{AR}^{-1-}\right.$ mice: $H_{(2,26)}=8.3, p=$ 0.015 ) (cf. Fig. $9 B$ and $A$; Fig. 9-1, available at https://doi.org/ 10.1523/JNEUROSCI.1004-18.2018.f9-1). To address the relevance of TLR2 to neuropathic pain relief, we then tested the TLR2/TLR4 antagonist RS-LPS (Lu et al., 2013) and the more selective neutralizing anti-TLR2 antibody mAb T2.5 (Meng et al., 2004) and showed that they both have an anti-allodynic effect (RS-LPS: $F_{(6,96)}=4.8$, $p<0.001$; T2.5: $F_{(7,84)}=4.0, p<0.001$ ) (Fig. $9 C$ and Fig. 9-11, available at https://doi.org/10.1523/JNEUROSCI.1004-18. 2018.f9-1).
Acute and prolonged amitriptyline treatments recruit different mechanism

We identified two independent mechanisms by which duloxetine can relieve neuropathic pain. To generalize these findings, we tested a representative of another family of antidepressant drugs, the tricyclic antidepressant amitriptyline, which is also prescribed as a first-line treatment for neuropathic pain. For delivery, we used either intraperitoneal administration or oral administration after establishing the dose-response curve of acute (Fig. 10 A, B) and chronic (Fig. 10C) actions. As observed for duloxetine, the lesion of descending noradrenergic pathways suppressed the capacity of acute (but not chronic) amitriptyline to relieve neuropathic allodynia (acute: $F_{(2,18)}=8.3, p<0.001$ ) (Fig. $10 D$ and Fig. 10-11, available at https://doi.org/10.1523/JNEUROSCI.1004-18.2018.f10-1). Reciprocally, suppressing the peripheral sources of noradrenaline prevented the effect of chronic (but not acute) amitriptyline (chronic: $F_{(9,162)}=6.8, p<0.001$ ) (Fig. $10 D$ and Fig. 10-1, available at https:// doi.org/10.1523/JNEUROSCI.1004-18.2018.f10-1). We then evaluated the role of adrenoceptors and observed that $\alpha_{2}$ adrenoceptors (but not $\beta$ adrenoceptors) mediated acute amitriptyline action (yohimbine: $F_{(1,16)}=6.3, p=0.005$ ) (Fig. $10 E$ and Fig. $10-1$, available at https://doi.org/10.1523/JNEUROSCI.1004-18.2018.f10-1), whereas the delayed action of chronic amitriptyline was lost in $\beta_{2}-\mathrm{AR}^{-1-}$ mice $\left(F_{(8,120)}=3.6, p<0.001\right)$ (Fig. $10 F$ and Fig. 10-1, available at https://doi.org/10.1523/JNEUROSCI.1004-18.2018.f10-1). This anti-allodynic action of chronic amitriptyline required DOR, but neither MOR nor KOR $\left(\mathrm{DOR}^{-1-}: F_{(8,120)}=3.4, p<0.001\right)$ (Fig. $10 G$ 

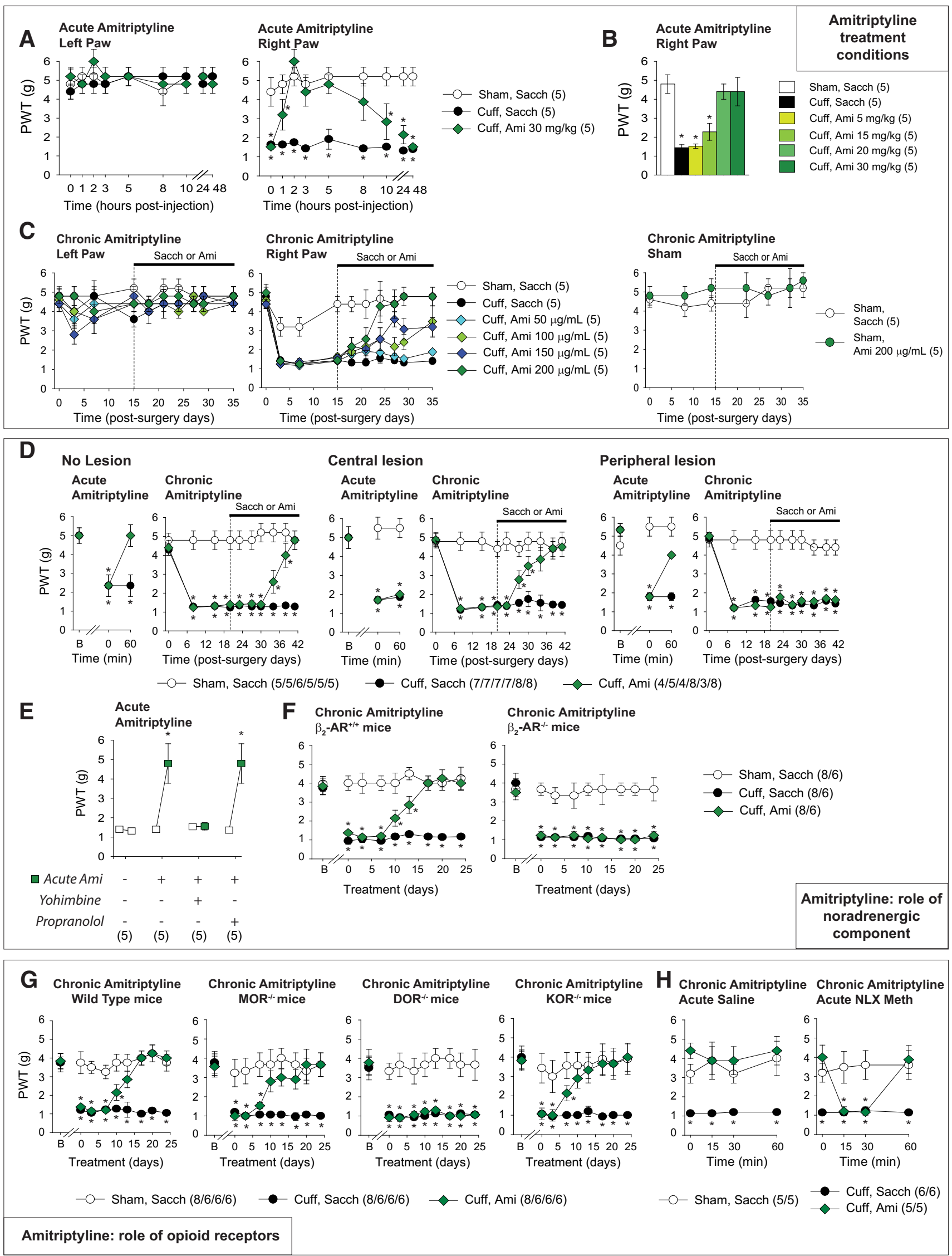

Figure 10. Adrenergic mechanism and opioid component of amitriptyline. Neuropathic pain was induced by inserting a cuff around the main branch of the sciatic nerve. Amitriptyline treatments started at least 2 weeks postsurgery. The presence and relief of mechanical allodynia were tested using von Frey filaments. $A$, The acute per os administration of amitriptyline ( $30 \mathrm{mg} / \mathrm{kg}$ ) had an acute anti-allodynic effect at 2 to $8 \mathrm{~h}$. B. Two hours after administration, acute amitriptyline produced an anti-allodynic effect at oral doses of 20 and (Figure legend continues.) 
and Fig. 10-1, available at https://doi.org/ 10.1523/JNEUROSCI.1004-18.2018.f10-1), with a likely peripheral location of the required opioid receptors, as shown by naloxone methiodide action $\left(F_{(3,39)}=8.8\right.$, $p<0.001$ ) (Fig. $10 \mathrm{H}$ and Fig. 10-1, available at https://doi.org/10.1523/JNEUROSCI.1004-18.2018.f10-1). Furthermore, the overexpression of mTNF- $\alpha$ in the lumbar dorsal root ganglia of nerve injured male mice was also corrected by chronic amitriptyline treatment $\left(H_{(2,21)}=6.4, p=0.041\right)$ (Fig. 11 and Fig. 11-1, available at https:// doi.org/10.1523/JNEUROSCI.1004-18. 2018.f11-1). These data converge with duloxetine data, thus supporting the conclusion that, for two types of antidepressant medications, different mechanisms underlie their acute and delayed actions on neuropathic pain.

\section{Discussion}

Although antidepressants have been used for several years as first-line treatment against neuropathic pain, their mechanism of action remains in part elusive (Kremer et al., 2016a). The present study combined data collected in a preclinical model of neuropathic pain and plasma dosage in the clinical setting to understand how antidepressant drugs act on neuropathic pain. We provide evidence for two distinct adrenergic-mediated mechanisms by which the SSNRI duloxetine and the tricyclic antidepressant amitriptyline relieved neuropathic allodynia. One of these mechanisms is central, requiring descending noradrenergic inhibitory controls and $\alpha_{2 \mathrm{~A}}$ adrenoceptors, as well as the MOR and DOR components of the opioid system. This central mechanism results in a rapid and transitory relief of mechanical allodynia and it converges with various reports from the animal-based scientific literature (Ardid and

$\leftarrow$

(Figure legend continued.) $30 \mathrm{mg} / \mathrm{kg}$. C, Chronic oral amitriptyline dose-dependently suppressed cuff-induced allodynia at doses 100,150, or $200 \mu \mathrm{g} / \mathrm{ml}$. No effect was observed on the contralateral paw or on the nociceptive threshold of sham mice. $\boldsymbol{D}$, Guanethidine (peripheral lesion, $30 \mathrm{mg} / \mathrm{kg}$, i.p.) and 6-OHDA (central lesion, $20 \mu \mathrm{g}$ per mouse, i.t.) allowed lesioning the noradrenergic fibers. Acutely, a high dose of amitriptyline $(15 \mathrm{mg} / \mathrm{kg}$, i.p.) induced a rapid anti-allodynic effect (left graph). This effect was prevented by a central (middle graph), but not peripheral (right graph), noradrenergic lesion. Chronic amitriptyline $(200 \mu \mathrm{g} / \mathrm{ml})$ exerted a delayed anti-allodynic effect (left graph). The peripheral (right graph), but not central (middle graph), noradrenergic lesion suppressed the long-term anti-allodynic action of amitriptyline. ("Chronic No Lesion" $n /$ "Acute No Lesion" n/"Chronic Peripheral Lesion" n/"Acute Peripheral Lesion" $n /$ "Chronic Central Lesion" $n / " A c u t e$ Central Lesion" $n$ are given in brackets). $\boldsymbol{E}$, In nerveinjured mice, yohimbine ( $\alpha 2$ adrenoceptor antagonist, $20 \mu \mathrm{g} / \mathrm{ml}$ for $5 \mathrm{~d}$ ), but not propranolol ( $\beta$ adrenoceptor antagonist, $50 \mu \mathrm{g} / \mathrm{ml}$ for $5 \mathrm{~d}$ ), suppressed the acute action of per os amitriptyline $(20 \mathrm{mg} / \mathrm{kg}) .{ }^{*} p<0.05$ compared with time before acute administration. $\boldsymbol{F}, \ln \beta 2$ $\mathrm{AR}^{+/+}$mice, chronic oral amitriptyline $(200 \mu \mathrm{g} / \mathrm{ml})$ suppressed mechanical allodynia but remained ineffective in $\beta 2-A R^{-1-}$ mice. " $\beta 2-A R^{+/+} n / \beta 2-A R^{-/-} n^{\prime \prime}$ are given in brackets. $G$, In WT mice, in $\mathrm{MOR}^{-1-}$ and in $\mathrm{KOR}^{-1-}$ mice, chronic oral amitriptyline treatment suppressed the ipsilateral cuff-induced allodynia, whereas it remained ineffective in $D O R^{-1-}$ mice ("WT $n / \mathrm{MOR}^{-1-} n / \mathrm{DOR}{ }^{-1-} n / \mathrm{KOR}^{-1-} n$ " are given in brackets). $\boldsymbol{H}$, An acute injection of the opioid receptor antagonist, naloxone methiodide $(5 \mathrm{mg} / \mathrm{kg}$, S.c.) induced a relapse of allodynia in chronic amitriptyline-treated mice ("Saline $n / \mathrm{NLX}$ Meth $n$ " are given in bracket). Ami, Amitriptyline; Sacch, saccharin. Data are expressed as mean \pm SEM. "B" corresponds to the mechanical threshold sensitivity of right paw before surgery. AR, Adrenoceptor. $n$ values are given in brackets. ${ }^{*} p<0.05$ compared with sham saccharin groups. ANOVA with repeated measures was used for $\boldsymbol{A}, \boldsymbol{C}, \boldsymbol{D}$, and $\boldsymbol{F}-\boldsymbol{H}$; one-way ANOVA was used for $\boldsymbol{B}$ and $\boldsymbol{E}$. Detailed statistics are provided in Figure 10-1, available at https://doi.org/10.1523/JNEUROSCI.1004-18. 2018.f10-1.
Guilbaud, 1992; Marchand et al., 2003; Ozdoğan et al., 2004; Suzuki et al., 2008; Cegielska-Perun et al., 2013; Hajhashemi et al., 2014). The other mechanism is peripheral, delayed but longer lasting (Salvat et al., 2018), and requires noradrenaline from peripheral sympathetic endings and $\beta_{2}$ adrenoceptors, as well as the DOR component of the opioid system (Benbouzid et al., 2008b; Yalcin et al., 2009a,b; Bohren et al., 2013; Choucair-Jaafar et al., 2014). This peripheral mechanism provides a delayed relief of mechanical allodynia, converges with reports from studies on chronic nortriptyline (Yalcin et al., 2009b; Bohren et al., 2013), and relies on an anti-neuroimmune action. Together, these findings suggest that the apparent mechanistic discrepancies previously reported in the literature result from differences in experimental procedures, which may more specifically highlight one or the other (or both) of the above mechanisms depending on the protocol chosen to deliver and test the action of the antidepressant drugs.

To explore the clinical relevance of these mechanisms, we compared drug levels in the animal model and in patients relieved by at least $30 \%$ of their peripheral neuropathic pain by the daily intake of a $60 \mathrm{mg}$ dose of duloxetine. To circumvent interspecies differences concerning intestinal absorption, metabolism, or bioavailability of the drug, we directly performed plasma dosage of duloxetine. Blood sampling in patients was done at both peak levels (Senthamil Selvan et al., 2007) and residual levels (before daily drug intake) and we compared the results with those obtained in animals under acute and chronic treatments. We showed that plasma concentrations in chronically treated neuropathic pain patients are in agreement with reports from the literature that are based on acute delivery in naive volunteers (Skinner et al., 2003; Reddy et al., 2012). We also observed that these concentrations are in good agreement with the ones measured in animals under chronic treatment. Moreover, the human versus mouse $K_{\mathrm{i}}$ values for duloxetine action on noradrenaline uptake are in a close range (7.5 vs $3.6 \mathrm{~nm}$ ) (Wong, 1998; Bymaster et al., 2005), which excludes a main interspecies confounder that would be related to differences in action on the noradrenergic transporter. Duloxetine concentrations observed in patients are in fact even slightly lower than the ones reached in the animal model, which may be related to the fact that the animal studies are based on a full recovery from mechanical allodynia, whereas clinical criteria for efficacy are based on a partial $(30 \%)$ decrease in pain intensity. 
To further investigate the peripheral mechanism of action of duloxetine, we conducted a transcriptomic analysis in dorsal root ganglia. This emphasized the extensive remodeling of the extracellular matrix following nerve injury, as illustrated by changes in metalloproteases, which converges with reports from other neuropathic pain models or from other species (Komori et al., 2007; Wu et al., 2016; Hirai et al., 2017). Metalloproteases from the extracellular matrix, which are expressed by dorsal root ganglia neurons and satellite cells, regulate the proliferation and differentiation of peripheral (Chattopadhyay and Shubayev, 2009; Berta et al., 2012) and central (Kawasaki et al., 2008) glial cells and contribute to the development of neuropathic pain (Ji et al., 2009). Therefore, a recruitment of glial and immunocompetent cells is among the consequences of extracellular matrix alteration (Kawasaki et al., 2008). In this context, our transcriptomic analysis highlighted an anti-neuroimmune action of duloxetine. Neuroinflammation, which is often poorly sensitive to classical nonsteroidal anti-inflammatory drugs (Colloca et al., 2017), is associated with neuropathic pain pathophysiology (Ellis and Bennett, 2013; Lees et al., 2015). Our data suggest that chronically administered antidepressant drugs may relieve neuropathic pain by targeting these mechanisms. Interestingly, the anti-neuroimmune property of antidepressant drugs may not be limited to their action on neuropathic pain. Indeed, major depression can also be associated with inflammation (Dantzer et al., 2008; Walker et al., 2014; Miller and Raison, 2016; Pariante, 2017) and antidepressant drugs have been proposed to affect immune/glial responses and cytokines (Köhler et al., 2018; Więdłocha et al., 2018).

The TNF- $\alpha-\mathrm{NF}-\kappa \mathrm{B}$ pathway is a key regulator of the production of proinflammatory cytokines and of immune and glial responses (Makarov, 2000) and TNF- $\alpha$ itself, which is located both upstream and downstream of this pathway (Ledeboer et al., 2005; Kaltschmidt and Kaltschmidt, 2009; Lee et al., 2009), has been associated with the pathophysiology of neuropathic pain (Empl et al., 2001; Uçeyler et al., 2007; Leung and Cahill, 2010; Wang et al., 2016) and has even been proposed as a potential biomarker for chronic neuropathic pain after spinal cord injury in patients (Xu et al., 2015). In the dorsal root ganglia, we have previously observed that mTNF- $\alpha$ was produced by satellite glial cells (Bohren et al., 2013), which might contribute to neuropathic allodynia by influencing the nearby nociceptors through a local cell-cell signaling communication. We show here that chronic duloxetine, as well as chronic amitriptyline, suppressed the increase in dorsal root ganglia mTNF- $\alpha$ levels that accompanied nerve injury. This action could have therapeutic relevance. Indeed, the loss of mTNF- $\alpha$ overexpression has also been observed after prolonged treatments with other antidepressant drugs (Bohren et al., 2013), as well as with a gabapentinoid (Kremer et al., 2016b), the other first-line treatment for neuropathic pain. Beyond this convergence in treatment action, we showed that adalimumab and certolizumab, two anti-TNF- $\alpha$ biotherapies, as well as an NF- $\kappa \mathrm{B}$ inhibitor, were effective in alleviating neuropathic allodynia in the animal model, which supports a key pathophysiological role of this cytokine. A potential therapeutic benefit of anti-TNF- $\alpha$ biotherapies in neuropathic pain or in chronic back or disc-related pain has been suggested both in patients (Korhonen et al., 2004; Tobinick and Davoodifar, 2004; Genevay et al., 2010, 2012; Ohtori et al., 2012) and in animal models (Sommer et al., 2001; Zanella et al., 2008; Watanabe et al., 2011; Bohren et al., 2013; Coelho et al., 2014). Interestingly, whereas anti-TNF- $\alpha$ biotherapies increase the risk of herpes zoster (Strangfeld et al., 2009; Failla et al., 2012; Di Costanzo et al., 2013; Nimmrich and Horneff, 2015), the incidence of posther- petic neuralgia might be lower (Javed et al., 2011). However, whereas our data provide mechanistic evidence for the antineuroimmune action of antidepressant drugs, direct anti-TNF- $\alpha$ treatments may not be appropriate for a large clinical use in a neuropathic pain context. Indeed, the benefits/risks balance can be questioned due to major adverse effects, including increased risks of infections and of cancer (Pereira et al., 2015; Cosnes, 2017). In this context, it may be of interest to develop new therapies that would blunt pathological TNF- $\alpha$ overexpression, but partly maintain its physiological production.

Our results also highlighted the contribution of other members of the TNF- $\alpha-\mathrm{NF}-\kappa \mathrm{B}$ signaling pathway, including TLR2. TLRs are type I transmembrane receptors expressed in innate immune cells that detect pathogen-associated molecules and trigger inflammatory responses (Hayward and Lee, 2014). Due to their ability to also recognize damage-associated molecular pattern molecules (DAMPs), TLRs can be involved in glial activation and contribute to noninfectious disorders, including persistent pain (Hayward and Lee, 2014; Kato and Svensson, 2015). Indeed, it has been suggested that TLR2 is responsible for the nerve injury-induced satellite glial cell activation and TNF- $\alpha$ upregulation in the dorsal root ganglia and thereby contributes to the development of neuropathic pain (Kim et al., 2007, 2011). A repeated intrathecal delivery of a nonselective TLR2/4 antagonist can attenuate allodynia in a neuropathic pain model (Jurga et al., 2016). Here, we show that allodynia relief can also be observed after the systemic delivery of such antagonist, as well as with a selective anti-TLR2 biotherapy. Interestingly, anti-TLR2 drugs are presently under investigation for human application in myelodysplastic syndrome and in preventing delayed renal graft function. We show here that duloxetine, through a $\beta_{2}$ adrenoceptor-mediated mechanism, indirectly acts as an anti-TLR 2 by regulating its overexpression in a pathological context.

In conclusion, we identified two independent mechanisms contributing to the action of antidepressant drugs on neuropathic pain. In particular, our transcriptomic analysis suggests that the peripheral component of duloxetine action involves the inhibition of neuroimmune mechanisms accompanying nerve injury, including the downregulation of the TNF- $\alpha-\mathrm{NF}-\kappa \mathrm{B}$ signaling pathway. These findings reveal antidepressant drugs as indirectly affecting neuroinflammatory mechanisms, which, beyond the pain field, might also be relevant to the psychiatric applications of these molecules.

\section{References}

Anders S, Pyl PT, Huber W (2015) HTSeq-a python framework to work with high-throughput sequencing data. Bioinformatics 31:166-169. CrossRef Medline

Ardid D, Guilbaud G (1992) Antinociceptive effects of acute and 'chronic' injections of tricyclic antidepressant drugs in a new model of mononeuropathy in rats. Pain 49:279-287. CrossRef Medline

Arsenault A, Sawynok J (2009) Perisurgical amitriptyline produces a preventive effect on afferent hypersensitivity following spared nerve injury. Pain 146:308-314. CrossRef Medline

Barrot M (2012) Tests and models of nociception and pain in rodents. Neuroscience 211:39-50. CrossRef Medline

Benbouzid M, Pallage V, Rajalu M, Waltisperger E, Doridot S, Poisbeau P, Freund-Mercier MJ, Barrot M (2008a) Sciatic nerve cuffing in mice: a model of sustained neuropathic pain. Eur J Pain 12:591-599. CrossRef Medline

Benbouzid M, Gavériaux-Ruff C, Yalcin I, Waltisperger E, Tessier LH, Muller A, Kieffer BL, Freund-Mercier MJ, Barrot M (2008b) Delta-opioid receptors are critical for tricyclic antidepressant treatment of neuropathic allodynia. Biol Psychiatry 63:633-636. CrossRef Medline

Berta T, Liu T, Liu YC, Xu ZZ, Ji RR (2012) Acute morphine activates sat- 
ellite glial cells and up-regulates IL-1beta in dorsal root ganglia in mice via matrix metalloprotease-9. Mol Pain 8:18. CrossRef Medline

Bohren Y, Karavelic D, Tessier LH, Yalcin I, Gavériaux-Ruff C, Kieffer BL, Freund-Mercier MJ, Barrot M (2010) Mu-opioid receptors are not necessary for nortriptyline treatment of neuropathic allodynia. Eur J Pain 14:700-704. CrossRef Medline

Bohren Y, Tessier LH, Megat S, Petitjean H, Hugel S, Daniel D, Kremer M, Fournel S, Hein L, Schlichter R, Freund-Mercier MJ, Yalcin I, Barrot M (2013) Antidepressants suppress neuropathic pain by a peripheral beta2adrenoceptor mediated anti-TNF-alpha mechanism. Neurobiol Dis 60: 39-50. CrossRef Medline

Bolger AM, Lohse M, Usadel B (2014) Trimmomatic: a flexible trimmer for illumina sequence data. Bioinformatics 30:2114-2120. CrossRef Medline

Bouhassira D, Attal N, Alchaar H, Boureau F, Brochet B, Bruxelle J, Cunin G, Fermanian J, Ginies P, Grun-Overdyking A, Jafari-Schluep H, LantériMinet M, Laurent B, Mick G, Serrie A, Valade D, Vicaut E (2005) Comparison of pain syndromes associated with nervous or somatic lesions and development of a new neuropathic pain diagnostic questionnaire (DN4). Pain 114:29-36. CrossRef Medline

Brumovsky PR (2016) Dorsal root ganglion neurons and tyrosine hydroxylase-an intriguing association with implications for sensation and pain. Pain 157:314-320. CrossRef Medline

Bymaster FP, Lee TC, Knadler MP, Detke MJ, Iyengar S (2005) The dual transporter inhibitor duloxetine: a review of its preclinical pharmacology, pharmacokinetic profile, and clinical results in depression. Curr Pharm Des 11:1475-1493. CrossRef Medline

Cegielska-Perun K, Bujalska-Zadrożny M, Tatarkiewicz J, Gąsińska E, Makulska-Nowak HE (2013) Venlafaxine and neuropathic pain. Pharmacology 91:69-76. CrossRef Medline

Chattopadhyay S, Shubayev VI (2009) MMP-9 controls schwann cell proliferation and phenotypic remodeling via IGF-1 and ErbB receptormediated activation of MEK/ERK pathway. Glia 57:1316-1325. CrossRef Medline

Choucair-Jaafar N, Salvat E, Freund-Mercier MJ, Barrot M (2014) The antiallodynic action of nortriptyline and terbutaline is mediated by beta(2) adrenoceptors and delta opioid receptors in the ob/ob model of diabetic polyneuropathy. Brain Res 1546:18-26. CrossRef Medline

Chruscinski AJ, Rohrer DK, Schauble E, Desai KH, Bernstein D, Kobilka BK (1999) Targeted disruption of the beta2 adrenergic receptor gene. J Biol Chem 274:16694-16700. CrossRef Medline

Coelho SC, Bastos-Pereira AL, Fraga D, Chichorro JG, Zampronio AR (2014) Etanercept reduces thermal and mechanical orofacial hyperalgesia following inflammation and neuropathic injury. Eur J Pain 18:957967. CrossRef Medline

Colloca L, Ludman T, Bouhassira D, Baron R, Dickenson AH, Yarnitsky D, Freeman R, Truini A, Attal N, Finnerup NB, Eccleston C, Kalso E, Bennett DL, Dworkin RH, Raja SN (2017) Neuropathic pain. Nat Rev Dis Primers 3:17002. CrossRef Medline

Cosnes J (2017) What should be done in inflammatory bowel disease patients with prior malignancy? Dig Dis 35:50-55. CrossRef Medline

da Huang W, Sherman BT, Lempicki RA (2009) Systematic and integrative analysis of large gene lists using DAVID bioinformatics resources. Nat Protoc 4:44-57. CrossRef Medline

Dantzer R, O'Connor JC, Freund GG, Johnson RW, Kelley KW (2008) From inflammation to sickness and depression: when the immune system subjugates the brain. Nat Rev Neurosci 9:46-56. CrossRef Medline

Di Costanzo L, Ayala F, Megna M, Gaudiello F, Patrì A, Balato N (2013) The risk of herpes zoster in the anti-TNF-alpha era: a case report and review of the literature. J Dermatol Case Rep 7:1-4. CrossRef Medline

Dierich A, Kieffer BL (2004) Knockout mouse models in pain research. Methods Mol Med 99:269-299. Medline

Dworkin RH, Turk DC, Farrar JT, Haythornthwaite JA, Jensen MP, Katz NP, Kerns RD, Stucki G, Allen RR, Bellamy N, Carr DB, Chandler J, Cowan P, Dionne R, Galer BS, Hertz S, Jadad AR, Kramer LD, Manning DC, Martin S, et al. (2005) Core outcome measures for chronic pain clinical trials: IMMPACT recommendations. Pain 113:9-19. CrossRef Medline

Ellis A, Bennett DL (2013) Neuroinflammation and the generation of neuropathic pain. Br J Anaesth 111:26-37. CrossRef Medline

Empl M, Renaud S, Erne B, Fuhr P, Straube A, Schaeren-Wiemers N, Steck AJ (2001) TNF-alpha expression in painful and nonpainful neuropathies. Neurology 56:1371-1377. CrossRef Medline

Failla V, Jacques J, Castronovo C, Nikkels AF (2012) Herpes zoster in pa- tients treated with biologicals. Dermatology 224:251-256. CrossRef Medline

Farmer WT, Abrahamsson T, Chierzi S, Lui C, Zaelzer C, Jones EV, Bally BP, Chen GG, Théroux JF, Peng J, Bourque CW, Charron F, Ernst C, Sjöström PJ, Murai KK (2016) Neurons diversify astrocytes in the adult brain through sonic hedgehog signaling. Science 351:849-854. CrossRef Medline

Filliol D, Ghozland S, Chluba J, Martin M, Matthes HW, Simonin F, Befort K, Gavériaux-Ruff C, Dierich A, LeMeur M, Valverde O, Maldonado R, Kieffer BL (2000) Mice deficient for delta- and mu-opioid receptors exhibit opposing alterations of emotional responses. Nat Genet 25:195-200. CrossRef Medline

Finnerup NB, Attal N, Haroutounian S, McNicol E, Baron R, Dworkin RH, Gilron I, Haanpää M, Hansson P, Jensen TS, Kamerman PR, Lund K, Moore A, Raja SN, Rice AS, Rowbotham M, Sena E, Siddall P, Smith BH, Wallace M (2015) Pharmacotherapy for neuropathic pain in adults: a systematic review and meta-analysis. Lancet Neurol 14:162-173. CrossRef Medline

Gavériaux-Ruff C, Kieffer BL (2002) Opioid receptor genes inactivated in mice: the highlights. Neuropeptides 36:62-71. CrossRef Medline

Genevay S, Viatte S, Finckh A, Zufferey P, Balagué F, Gabay C (2010) Adalimumab in severe and acute sciatica: a multicenter, randomized, doubleblind, placebo-controlled trial. Arthritis Rheum 62:2339-2346. CrossRef Medline

Genevay S, Finckh A, Zufferey P, Viatte S, Balagué F, Gabay C (2012) Adalimumab in acute sciatica reduces the long-term need for surgery: a 3-year follow-up of a randomised double-blind placebo-controlled trial. Ann Rheum Dis 71:560-562. CrossRef Medline

Hajhashemi V, Banafshe HR, Minaiyan M, Mesdaghinia A, Abed A (2014) Antinociceptive effects of venlafaxine in a rat model of peripheral neuropathy: role of alpha2-adrenergic receptors. Eur J Pharmacol 738:230 236. CrossRef Medline

Hayward JH, Lee SJ (2014) A decade of research on TLR2 discovering its pivotal role in glial activation and neuroinflammation in neurodegenerative diseases. Exp Neurobiol 23:138-147. CrossRef Medline

Hirai T, Mulpuri Y, Cheng Y, Xia Z, Li W, Ruangsri S, Spigelman I, Nishimura I (2017) Aberrant plasticity of peripheral sensory axons in a painful neuropathy. Sci Rep 7:3407. CrossRef Medline

Javed S, Kamili QU, Mendoza N, Tyring SK (2011) Possible association of lower rate of postherpetic neuralgia in patients on anti-tumor necrosis factor-alpha. J Med Virol 83:2051-2055. CrossRef Medline

Jensen MP, Karoly P (1992) Self-report scales and procedures for assessing pain in adults. In: Handbook of Pain Assessment (Turk DC and Melzack R, ed), pp135-151. New York: The Guilford Press.

Ji RR, Xu ZZ, Wang X, Lo EH (2009) Matrix metalloprotease regulation of neuropathic pain. Trends Pharmacol Sci 30:336-340. CrossRef Medline

Jurga AM, Rojewska E, Piotrowska A, Makuch W, Pilat D, Przewlocka B, Mika J (2016) Blockade of Toll-like receptors (TLR2, TLR4) attenuates pain and potentiates buprenorphine analgesia in a rat neuropathic pain model. Neural Plast 2016:5238730. CrossRef Medline

Kaltschmidt B, Kaltschmidt C (2009) NF-kappaB in the nervous system. Cold Spring Harb Perspect Biol 1:a001271. CrossRef Medline

Kato J, Svensson CI (2015) Role of extracellular damage-associated molecular pattern molecules (DAMPs) as mediators of persistent pain. Prog Mol Biol Transl Sci 131:251-279. CrossRef Medline

Kaufling J, Waltisperger E, Bourdy R, Valera A, Veinante P, Freund-Mercier MJ, Barrot M (2010) Pharmacological recruitment of the GABAergic tail of the ventral tegmental area by acute drug exposure. Br J Pharmacol 161:1677-1691. CrossRef Medline

Kawasaki Y, Xu ZZ, Wang X, Park JY, Zhuang ZY, Tan PH, Gao YJ, Roy K, Corfas G, Lo EH, Ji RR (2008) Distinct roles of matrix metalloproteases in the early- and late-phase development of neuropathic pain. Nat Med 14:331-336. CrossRef Medline

Kim D, Kim MA, Cho IH, Kim MS, Lee S, Jo EK, Choi SY, Park K, Kim JS, Akira S, Na HS, Oh SB, Lee SJ (2007) A critical role of toll-like receptor 2 in nerve injury-induced spinal cord glial cell activation and pain hypersensitivity. J Biol Chem 282:14975-14983. CrossRef Medline

Kim D, You B, Lim H, Lee SJ (2011) Toll-like receptor 2 contributes to chemokine gene expression and macrophage infiltration in the dorsal root ganglia after peripheral nerve injury. Mol Pain 7:74. CrossRef Medline

Köhler CA, Freitas TH, Stubbs B, Maes M, Solmi M, Veronese N, de Andrade 
NQ, Morris G, Fernandes BS, Brunoni AR, Herrmann N, Raison CL, Miller BJ, Lanctôt KL, Carvalho AF (2018) Peripheral alterations in cytokine and chemokine levels after antidepressant drug treatment for major depressive disorder: systematic review and meta-analysis. Mol Neurobiol 55:4195-4206. CrossRef Medline

Komori N, Takemori N, Kim HK, Singh A, Hwang SH, Foreman RD, Chung K, Chung JM, Matsumoto H (2007) Proteomics study of neuropathic and nonneuropathic dorsal root ganglia: altered protein regulation following segmental spinal nerve ligation injury. Physiol Genomics 29:215230. CrossRef Medline

Korhonen T, Karppinen J, Malmivaara A, Autio R, Niinimäki J, Paimela L, Kyllönen E, Lindgren KA, Tervonen O, Seitsalo S, Hurri H (2004) Efficacy of infliximab for disc herniation-induced sciatica: one-year followup. Spine 29:2115-2119. CrossRef Medline

Kremer M, Salvat E, Muller A, Yalcin I, Barrot M (2016a) Antidepressants and gabapentinoids in neuropathic pain: mechanistic insights. Neuroscience 338:183-206. CrossRef Medline

Kremer M, Yalcin I, Nexon L, Wurtz X, Ceredig RA, Daniel D, Hawkes RA, Salvat E, Barrot M (2016b) The anti-allodynic action of pregabalin in neuropathic pain is independent from the opioid system. Mol Pain 12: 1744806916636387. CrossRef Medline

Ledeboer A, Gamanos M, Lai W, Martin D, Maier SF, Watkins LR, Quan N (2005) Involvement of spinal cord nuclear factor kappaB activation in rat models of proinflammatory cytokine-mediated pain facilitation. Eur J Neurosci 22:1977-1986. CrossRef Medline

Lee KM, Jeon SM, Cho HJ (2009) Tumor necrosis factor receptor 1 induces interleukin-6 upregulation through NF-kappaB in a rat neuropathic pain model. Eur J Pain 13:794-806. CrossRef Medline

Lees JG, Fivelman B, Duffy SS, Makker PG, Perera CJ, Moalem-Taylor G (2015) Cytokines in neuropathic pain and associated depression. Mod Trends Pharmacopsychiatry 30:51-66. CrossRef Medline

Leung L, Cahill CM (2010) TNF-alpha and neuropathic pain-a review. J Neuroinflammation 7:27. CrossRef Medline

Love MI, Huber W, Anders S (2014) Moderated estimation of fold change and dispersion for RNA-Seq data with DESeq2. Genome Biol 15:550. CrossRef Medline

Lu Z, Zhang X, Li Y, Jin J, Huang Y (2013) TLR4 antagonist reduces earlystage atherosclerosis in diabetic apolipoprotein E-deficient mice. J Endocrinol 216:61-71. CrossRef Medline

Lutz PE, Tanti A, Gasecka A, Barnett-Burns S, Kim JJ, Zhou Y, Chen GG, Wakid M, Shaw M, Almeida D, Chay MA, Yang J, Larivière V, M'Boutchou MN, van Kempen LC, Yerko V, Prud'homme J, Davoli MA, Vaillancourt K, Théroux JF, et al. (2017) Association of a history of child abuse with impaired myelination in the anterior cingulate cortex: convergent epigenetic, transcriptional, and morphological evidence. Am J Psychiatry 174:1185-1194. CrossRef Medline

Makarov SS (2000) NF-kappaB as a therapeutic target in chronic inflammation: recent advances. Mol Med Today 6:441-448. CrossRef Medline

Marchand F, Ardid D, Chapuy E, Alloui A, Jourdan D, Eschalier A (2003) Evidence for an involvement of supraspinal delta- and spinal mu-opioid receptors in the antihyperalgesic effect of chronically administered clomipramine in mononeuropathic rats. J Pharmacol Exp Ther 307:268274. CrossRef Medline

Matthes HW, Maldonado R, Simonin F, Valverde O, Slowe S, Kitchen I, Befort K, Dierich A, Le Meur M, Dollé P, Tzavara E, Hanoune J, Roques BP, Kieffer BL (1996) Loss of morphine-induced analgesia, reward effect and withdrawal symptoms in mice lacking the mu-opioid-receptor gene. Nature 383:819-823. CrossRef Medline

Maussion G, Diallo AB, Gigek CO, Chen ES, Crapper L, Théroux JF, Chen GG, Vasuta C, Ernst C (2015) Investigation of genes important in neurodevelopment disorders in adult human brain. Hum Genet 134:10371053. CrossRef Medline

Max MB, Culnane M, Schafer SC, Gracely RH, Walther DJ, Smoller B, Dubner R (1987) Amitriptyline relieves diabetic neuropathy pain in patients with normal or depressed mood. Neurology 37:589-596. CrossRef Medline

McLachlan EM, Jänig W, Devor M, Michaelis M (1993) Peripheral nerve injury triggers noradrenergic sprouting within dorsal root ganglia. Nature 363:543-546. CrossRef Medline

Megat S, Bohren Y, Doridot S, Gavériaux-Ruff C, Kieffer BL, Freund-Mercier MJ, Yalcin I, Barrot M (2015) kappa-opioid receptors are not necessary for the antidepressant treatment of neuropathic pain. Br J Pharmacol 172:1034-1044. CrossRef Medline

Meng G, Rutz M, Schiemann M, Metzger J, Grabiec A, Schwandner R, Luppa PB, Ebel F, Busch DH, Bauer S, Wagner H, Kirschning CJ (2004) Antagonistic antibody prevents toll-like receptor 2-driven lethal shock-like syndromes. J Clin Invest 113:1473-1481. CrossRef Medline

Micó JA, Ardid D, Berrocoso E, Eschalier A (2006) Antidepressants and pain. Trends Pharmacol Sci 27:348-354. CrossRef Medline

Miller AH, Raison CL (2016) The role of inflammation in depression: from evolutionary imperative to modern treatment target. Nat Rev Immunol 16:22-34. CrossRef Medline

Nimmrich S, Horneff G (2015) Incidence of herpes zoster infections in juvenile idiopathic arthritis patients. Rheumatol Int 35:465-470. CrossRef Medline

Ohtori S, Miyagi M, Eguchi Y, Inoue G, Orita S, Ochiai N, Kishida S, Kuniyoshi K, Nakamura J, Aoki Y, Ishikawa T, Arai G, Kamoda H, Suzuki M, Takaso M, Furuya T, Toyone T, Takahashi K (2012) Epidural administration of spinal nerves with the tumor necrosis factor-alpha inhibitor, etanercept, compared with dexamethasone for treatment of sciatica in patients with lumbar spinal stenosis: a prospective randomized study. Spine 37:439-444. CrossRef Medline

Ozdoğan UK, Lähdesmäki J, Mansikka H, Scheinin M (2004) Loss of amitriptyline analgesia in alpha 2A-adrenoceptor deficient mice. Eur J Pharmacol 485:193-196. CrossRef Medline

Paoli F, Darcourt G, Cossa P (1960) Preliminary note on the action of imipramine in painful states [Article in French]. Rev Neurol (Paris) 102:503504. Medline

Pariante CM (2017) Why are depressed patients inflamed? A reflection on 20 years of research on depression, glucocorticoid resistance and inflammation. Eur Neuropsychopharmacol 27:554-559. CrossRef Medline

Perahia DG, Pritchett YL, Desaiah D, Raskin J (2006) Efficacy of duloxetine in painful symptoms: an analgesic or antidepressant effect? Int Clin Psychopharmacol 21:311-317. CrossRef Medline

Pereira R, Lago P, Faria R, Torres T (2015) Safety of anti-TNF-therapies in immune-mediated inflammatory diseases: focus on infections and malignancy. Drug Dev Res 76:419-427. CrossRef Medline

Pertovaara A (2006) Noradrenergic pain modulation. Prog Neurobiol 80: 53-83. CrossRef Medline

Ramer MS, Bisby MA (1998) Normal and injury-induced sympathetic innervation of rat dorsal root ganglia increases with age. J Comp Neurol 394:38-47. CrossRef Medline

Reddy DC, Bapuji A, Rao VS, Himabindu V, Rama Raju D, Syedba S, Ravikiran H (2012) Development and validation of a LC/MS/MS method for the determination of duloxetine in human plasma and its application to pharmacokinetic study. J Chem 9:899-911. CrossRef

Salvat E, Yalcin I, Muller A, Barrot M (2018) A comparison of early and late treatments on allodynia and its chronification in experimental neuropathic pain. Mol Pain 14:1744806917749683. CrossRef Medline

Schreiber S, Backer MM, Pick CG (1999) The antinociceptive effect of venlafaxine in mice is mediated through opioid and adrenergic mechanisms. Neurosci Lett 273:85-88. CrossRef Medline

Schroeder A, Mueller O, Stocker S, Salowsky R, Leiber M, Gassmann M, Lightfoot S, Menzel W, Granzow M, Ragg T (2006) The RIN: an RNA integrity number for assigning integrity values to RNA measurements. BMC Mol Biol 7:3. CrossRef Medline

Senthamil Selvan P, Gowda KV, Mandal U, Sam Solomon WD, Pal TK (2007) Determination of duloxetine in human plasma by liquid chromatography with atmospheric pressure ionization-tandem mass spectrometry and its application to pharmacokinetic study. J Chromatogr B Analyt Technol Biomed Life Sci 858:269-275. CrossRef Medline

Simonin F, Valverde O, Smadja C, Slowe S, Kitchen I, Dierich A, Le Meur M, Roques BP, Maldonado R, Kieffer BL (1998) Disruption of the kappaopioid receptor gene in mice enhances sensitivity to chemical visceral pain, impairs pharmacological actions of the selective kappa-agonist U-50,488H and attenuates morphine withdrawal. EMBO J 17:886-897. CrossRef Medline

Sindrup SH, Otto M, Finnerup NB, Jensen TS (2005) Antidepressants in the treatment of neuropathic pain. Basic Clin Pharmacol Toxicol 96:399409. CrossRef Medline

Skinner MH, Kuan HY, Pan A, Sathirakul K, Knadler MP, Gonzales CR, Yeo KP, Reddy S, Lim M, Ayan-Oshodi M, Wise SD (2003) Duloxetine is 
both an inhibitor and a substrate of cytochrome P4502D6 in healthy volunteers. Clin Pharmacol Ther 73:170-177. CrossRef Medline

Sommer C, Schäfers M, Marziniak M, Toyka KV (2001) Etanercept reduces hyperalgesia in experimental painful neuropathy. J Peripher Nerv Syst 6:67-72. CrossRef Medline

Strangfeld A, Listing J, Herzer P, Liebhaber A, Rockwitz K, Richter C, Zink A (2009) Risk of herpes zoster in patients with rheumatoid arthritis treated with anti-TNF-alpha agents. JAMA 301:737-744. CrossRef Medline

Subramanian A, Tamayo P, Mootha VK, Mukherjee S, Ebert BL, Gillette MA, Paulovich A, Pomeroy SL, Golub TR, Lander ES, Mesirov JP (2005) Gene set enrichment analysis: a knowledge-based approach for interpreting genome-wide expression profiles. Proc Natl Acad Sci U S A 102: 15545-15550. CrossRef Medline

Suzuki T, Ueta K, Tamagaki S, Mashimo T (2008) Anti-allodynic and antihyperalgesic effect of milnacipran in mice with spinal nerve ligation. Anesth Analg 106:1309-1315. CrossRef Medline

Tobinick E, Davoodifar S (2004) Efficacy of etanercept delivered by perispinal administration for chronic back and/or neck disc-related pain: a study of clinical observations in 143 patients. Curr Med Res Opin 20:10751085. CrossRef Medline

Trapnell C, Pachter L, Salzberg SL (2009) TopHat: discovering splice junctions with RNA-Seq. Bioinformatics 25:1105-1111. CrossRef Medline

Treede RD, Jensen TS, Campbell JN, Cruccu G, Dostrovsky JO, Griffin JW, Hansson P, Hughes R, Nurmikko T, Serra J (2008) Neuropathic pain: redefinition and a grading system for clinical and research purposes. Neurology 70:1630-1635. CrossRef Medline

Uçeyler N, Rogausch JP, Toyka KV, Sommer C (2007) Differential expression of cytokines in painful and painless neuropathies. Neurology 69:4249. CrossRef Medline

Walker AK, Kavelaars A, Heijnen CJ, Dantzer R (2014) Neuroinflammation and comorbidity of pain and depression. Pharmacol Rev 66:80-101. CrossRef Medline

Wang J, Ding CP, Yu J, Zeng XY, Han SP, Wang JY (2016) Dynamic distributions of tumor necrosis factor-alpha and its receptors in the red nucleus of rats with spared nerve injury. Neuropathology 36:346-353. CrossRef Medline

Wang Z, Gerstein M, Snyder M (2009) RNA-Seq: a revolutionary tool for transcriptomics. Nat Rev Genet 10:57-63. CrossRef Medline
Watanabe K, Yabuki S, Sekiguchi M, Kikuchi S, Konno S (2011) Etanercept attenuates pain-related behavior following compression of the dorsal root ganglion in the rat. Eur Spine J 20:1877-1884. CrossRef Medline

Watson CP, Evans RJ, Reed K, Merskey H, Goldsmith L, Warsh J (1982) Amitriptyline versus placebo in postherpetic neuralgia. Neurology 32: 671-673. CrossRef Medline

Więdłocha M, Marcinowicz P, Krupa R, Janoska-Jaździk M, Janus M, Dębowska W, Mosiołek A, Waszkiewicz N, Szulc A (2018) Effect of antidepressant treatment on peripheral inflammation markers: a metaanalysis. Prog Neuropsychopharmacol Biol Psychiatry 80:217-226. CrossRef Medline

Wong DT (1998) Duloxetine (LY 248686): an inhibitor of serotonin and noradrenaline uptake and an antidepressant drug candidate. Expert Opin Investig Drugs 7:1691-1699. CrossRef Medline

Wu S, Marie Lutz B, Miao X, Liang L, Mo K, Chang YJ, Du P, Soteropoulos P, Tian B, Kaufman AG, Bekker A, Hu Y, Tao YX (2016) Dorsal root ganglion transcriptome analysis following peripheral nerve injury in mice. Mol Pain 12:1744806916629048. CrossRef Medline

Xu J, E X, Liu H, Li F, Cao Y, Tian J, Yan J (2015) Tumor necrosis factoralpha is a potential diagnostic biomarker for chronic neuropathic pain after spinal cord injury. Neurosci Lett 595:30-34. CrossRef Medline

Yalcin I, Tessier LH, Petit-Demoulière N, Doridot S, Hein L, Freund-Mercier MJ, Barrot M (2009a) Beta2-adrenoceptors are essential for desipramine, venlafaxine or reboxetine action in neuropathic pain. Neurobiol Dis 33:386-394. CrossRef Medline

Yalcin I, Choucair-Jaafar N, Benbouzid M, Tessier LH, Muller A, Hein L, Freund-Mercier MJ, Barrot M (2009b) beta(2)-adrenoceptors are critical for antidepressant treatment of neuropathic pain. Ann Neurol 65: 218-225. CrossRef Medline

Yalcin I, Megat S, Barthas F, Waltisperger E, Kremer M, Salvat E, Barrot M (2014) The sciatic nerve cuffing model of neuropathic pain in mice. J Vis Exp 89: e51608. CrossRef Medline

Zanella JM, Burright EN, Hildebrand K, Hobot C, Cox M, Christoferson L, McKay WF (2008) Effect of etanercept, a tumor necrosis factor-alpha inhibitor, on neuropathic pain in the rat chronic constriction injury model. Spine 33:227-234. CrossRef Medline 